\title{
Environmental Management of the Public Lands $\dagger$
}

\author{
Ira Michael Heyman* \\ Robert H. Twiss**
}

In this Article, Professors Heyman and Twiss discuss possible reshaping of legal and administrative systems to consider the environmental implications of actions taken by land management agencies. By focusing on the Forest Service, and particularly its activity of timber harvesting, a methodology is proposed for dealing with the extraordinary complexity of problems that must be faced in order to make environmentally sound planning and management decisions. In evaluating this agency's activites in terms of the developed criteria, the authors conclude with a number of suggestions for strengthening the systems used by the Forest Service and other federal land management agencies.

Law-trained persons have a multitude of tasks to perform to protect environmental values. The range of these tasks mcludes dramatic opportunities for widely publicized litigations to halt conceived degrading activities, ${ }^{1}$ case-by-case development of expanded common law remedies, ${ }^{2}$ fashioning of new constitutional theory, ${ }^{3}$ drafting and im-

$\dagger$ This Article is based on a much longer monograph written by the authors as a consultant report to the Public Land Law Review Commission: U.S. Dep'T or CoMMerce, Public LaNd Policy and the ENVIronment, Part I, The Legal aNd AdMINISTRATIVE FrAmewORK FOR ENVIRONMENTAL MANAGEMenT (1970). Needless to say, the opmions expressed are those of the authors and not of the Commission or its staff. We would like to thank Messrs. Donald Gralnek and Alan Greenwald, 1970 graduates of the University of California, School of Law, who were research assistants in the preparation of the report to the Commission.

* Professor of Law and City Planning, University of California, Berkeley. B.A. 1951, Dartmouth; LL.B. 1965, Yale University.

** Associate Professor of Environmental Planning, University of California, Berkeley. A.B. 1956, San Jose State College; M.S. 1960, Ph.D. 1962, University of Michigan.

1. See, e.g., Scenic Hudson Preservation Conf. v. FPC, 354 F.2d 608 (2d Cir. 1965), cert. denied, 384 U.S. 941 (1966) (licensing of power plant on Hudson River remanded); D.C. Fed'n v. Volpe, 316 F. Supp. 754 (D.D.C. 1970) (temporary injunction against construction of bridge over Potomac River); Wilderness Soc'y v. Hickel, 1 BNA ENVIRONMENT REP.-CASEs 1335 (D.D.C. Sept. 16, 1970) thereinafter cited as 1 ENVIR. REP.-CASEs] (preliminary injunction barring issuance of federal permit for laul road needed for trans-Alaska pipeline system).

2. See, e.g., Boomer v. Atlantic Cement Co., 26 N.Y.2d 219, 257 N.E.2d 870, 309 N.Y.S.2d 312 (1970); Miami v. Coral Gables, 240 So. 2d 499 (Fla. App. 1970); Westchester Hoineowners v. Los Angeles, 1 ENVIR. ReP.-CASEs 1243 (L.A. County Super. Ct. 1970).

3. Roberts, The Right to a Decent Environment; E=MC2: Environment Equals 
plementing new statutes, ${ }^{4}$ and administrative litigation. ${ }^{5}$ A less dramatic legal task is resliaping the legal and administrative systems of governmental agencies so that environmental implications are properly taken into account in agency decisions.

This Article deals with this latter subject, but is not exhaustive in scope. It discusses only the management of federally owned lands; where government, as proprietor, has significantly more power, both legal and political, than it does as a regulator of activities on privately owned land. To accomplish this task, the Article first sets forth criteria for sound environmental management and then apphies those criteria to one set of activities of one land management agency-timber liarvesting activities of the Forest Service. This example illustrates an effective methodology which inay be followed first, to uncover weaknesses in planning and management systems that are causally related to harmful environmental consequences and, second, to suggest changes in these systems that will minimize the chances of sucli occurrences. The major focus here is an analysis of the extent to which the environmental risks attendant to day-to-day, as well as long-range, resource and use ${ }^{\mathfrak{b}}$ decisions are effectively brought to the attention of agency personnel. This inquiry is not concerned centrally with what decisions they make once confronted with good environmental data. ${ }^{7}$

Man Times Courts Redoubling Their Efforts, 55 CoRnell L. REv. 674 (1970); Note, Toward a Constitutionally Protected Environment, 56 VA. L. REv. 458 (1970).

4. E.g., The National Environmental Policy Act of 1969, 42 U.S.C. $\$ \$ 4321-47$ (Supp. V, 1970); The Wild and Scenic Rivers Act, 16 U.S.C. \$\$ 1271-87 (Supp. V, 1970); see the Federal Water Pollution Control Act, 33 U.S.C. \$\$ 466-66k (1964), as amended, Water Quality Improvenent Act of 1970, Pub. L. No. 91-224, 84 Stat. 91 (to be codified as 33 U.S.C. \$\$ 1151-75); Barry, The Evolution of the Enforcement Provisions of the Federal Water Pollution Control Act: A Study of the Difficulty in Developing Effective Legislation, 68 Mrch. L. REv. 1103 (1970); Tarlock \& Tippy, The Wild and Scenic Rivers Act of 1968, 55 CoRNELL L. Rev. 707 (1970).

5. See Sive, Some Thoughts of An Environmental Lawyer in the Wilderness of Administrative Law, 70 CoLuM. L. Rev. 612 (1970).

6. "Resource" and "use" are convenient categories for discussing many of the activities that are carred out on the public lands. "Resource" connotes the material fruits of these lands such as timber, grazing fodder, minerals, and water. Resource activities are thus timber liarvesting and fire control, grazing, mining, and waterslied enhancenent. "Use" connotes activities that do not consume resources, except imcidentally. Examples include both passive and active recreation and rights of way. On occasion in this Article the word "goods" is used for resources and the word "services" for uses.

7. For instance, in evaluating the Mineral King Controversy [Sierra Club v. Hickel, 433 F.2d 24 (9th Cir. 1970)], the planning and management systems of the Forest Service and the National Park Service would be examined to determine whether they produced adequate data available to the public upon which sound environmental predictions could be made, whether these data entered into the decisions to issue permits for the intended developinent, whether the public liad adequate opportunity to seek to affect the decisions that were made, and whether the agencies possessed ample authority to make and implenient a wise decision under the circumstances. Whether 
Part I commences with a description of various environmental impacts produced by activities carried out on the public lands. Examples are used to illustrate the extraordinary complexity of problems that must be faced in order to make environmentally sound planning and management decisions. Part II then postulates a number of environmental management criteria. Parts III, IV and V evaluate the Forest Service system for planning and managing timber harvesting against these criteria, and offer a number of suggestions for strengthening the systems for planning and management used by the Forest Service and other federal land management agencies.

ENVIRONMENTAL IMPACTS OF PUBLIC LAND USE

The federal land management agencies-primarily the Forest Service, the National Park Service, and the Bureau of Land Managementcontrol large areas of land. ${ }^{8}$ Charged by statute to produce various goods and services on these lands, ${ }^{9}$ they determine what activities will occur, in what locations, at what times, and under what conditions. ${ }^{10}$ Environmental problems created by these land use activities are very diverse, ranging from water pollution to decimation of wildlife and soil erosion. $^{11}$ A sound system of environmental management must be

use or preservation in that instance should be preferred would not be within the scope of this inquiry.

8. As of 1967 , the federal governinent owned 764.8 million acres of the over two billion acres contained in the 50 states. 1 HERMAN RUTH \& Assoc., Regional and Local Land Use Planning, in Public Land Law Review COMM'N IV-2 (1969) [hereinafter cited as Land Use Planning Study]. The Forest Service managed 187 million acres [id. at III-1], the National Park Service, 26.5 million [id. at V-2], and the Bureau of Land Management, 480 million [id. at IV-2].

9. 16 U.S.C. $\$ \S 528-31$ (1964) (Forest Service); 43 U.S.C. $\$ \S 1411-18$ (1964) (Bureau of Land Management); 16 U.S.C. $\$ 1$ (1964) (National Park Service).

10. In some instances, production of goods or services is antithetical to certain types of environmental protection mandated by Congress. For example, Congress has made the determination in the Wilderness Act, 16 U.S.C. $\$ \$ 1131-36$ (1964), that most resources in certain areas will be left largely untouched in the interest of preservation. Most federally owned acreage, however, is devoted to the production of goods and services as provided by statute: lands under the jurisdiction of the Forest Service to the production of timber, forage, recreation, water and wildlife [see note 8 supra]; lands inanaged by the Bureau of Land Management for these purposes and others, most prominently to mineral production and grazing. See note 8 supra.

11. The land related activities are carried out by nunnerous persons. Sometimes agency personnel are centrally concerned, as in the improvement of wildlife habitat or the construction and management of campsites in the national forests. At other times, the functions are carried out by private corporations or persons who operate largely as a matter of right-for example, in the location and exploitatiou of certain mining claimsor under contract or special permit-for example, in timber sales or in the construction and operation of a ski resort or a hotel.

In addition, federal lands are often used by other agencies for purposes unrelated 
capable of foreseeing these problems through an analysis of "environmental impacts."12 Environmental planning and management must consider the human values at stake and foresee the incidence of such impacts on the natural environment.

\section{A. The Nature of Environmental Impacts}

"Environmental impacts," as used here, refers to the effects of man's activities on a natural ecosystem. These activities change what heretofore existed. Sometimes the changes are clearly deleterious from anyone's perspective. Other changes can be viewed universally as beneficial. Most, however, have both effects and whether in sum they are good or bad depends on the values of the observer. ${ }^{13}$ Timber harvest can yield improved habitat for deer and other wildlife, but at the same time it may eliminate other types of natural vegetation that are valued for scenic or scientific reasons. Impact may favor one aspect of the natural environment over another, creating an environment useful to some people, distressing to others. For example, a reservoir creates an environment for water skiing at the expense of fast moving streams for white-water canoeing or nature study.

The extent of impacts is an important consideration in analysis of the worth of the activity which causes them. Effects can be local, as in the digging of a sinall exploratory mining pit, or have far-reaching effects, as in water or air pollution, or in a powerline clearing that can be seen for many miles. Effects can be primary only, or have secondary, tertiary, or further ecological ramifications. Sediment in a stream, for instance, has not only the primary effect of reducing the water clarity of a lake, but, inter alia, it holds the sun's energy, raises the water temperature, reduces water turnover, and favors algal production which further reduces clarity. ${ }^{14}$ Similarly, consequences may be short-run or long-run, as in the use of pesticides which degrade quickly, or last for years. ${ }^{15}$

to the missions of the managing agencies. Thus, reclamation and flood control dams are often located on Forest Service or Bureau of Land Management lands. Their locations are selected, and they are constructed, and operated by the Bureau of Reclamation and the Corps of Engineers. State, local, and federal roads cross these lands, as do gas lines, power lines, and other utilities. Each of these activities may pose immediate and long-run environmental dangers.

12. "Environmental impacts" are coped with as a matter of experience in resource management. Some are at least partly understood scientifically. But few, it is safe to say, are comprehended in terms of ultimate ecological ramifications over the long run.

13. For broad coverage of this topic see THE FUTURE ENVIRONMENTS OF NORTH America (Darling, Fraser \& Milton eds. 1966); MaN's Role IN Changing the Face OF THE EARTH (W. Thomas, Jr. ed. 1956).

14. See F. RUTTNER, Fundamentals OF LIMNOLOGY 184-85 (1953).

15. See R. Rudd, Pesticides and the Living Landscape (1967). 
The ecological situation in which an impact occurs also bears on the extent of impact. A small trail cut through an ecologically stable rain forest may be quickly overgrown. On the other hand, even a small trail through delicate and unstable tundra, or high mountain meadow, may create a scar and a new drainage channel lasting hundreds of years or resulting in essentially irreversible changes. ${ }^{16}$

Impacts are not necessarily direct results of specific types of use, but rather of the actions associated with such uses; for example, trenching, drainage, land fill, burning, clearing of vegetation, paving, and the like. Thus, construction of a major canpground might create more ecological damage than selective logging, a use seemingly more destructive of ecological values. Or the reverse could be the case, depending on the nature of the site and the way in which the cainpsite construction or logging operation is carried out. ${ }^{17}$ Despite this, important decisions in public land policy and planning, such as zoning and the dedication of lands to wilderness, are based on assumptions about the degree to which impacts, usually adverse ones, follow from a type of land use. ${ }^{18}$ Therefore, it is important to examine some major types of land uses and the impacts commonly associated with them. ${ }^{19}$

\section{B. A Survey of Impacts from Particular Land Uses}

\section{Land Occupancy}

Roads, utilities, buildings and other similar forms of land occupancy are not only significant in their own right, as in interstate highways or gas or power transmission lines, but also account for much of the impact associated with tunber harvest, recreation and other land uses. Actions often taken in connection with these uses, and their associated impacts, are numerous. Road building cut-and-fill operations can trigger landslides, expose steep slopes to erosion, block or reshape stream channels, divert or concentrate surface water and ground water flow, ${ }^{20}$ and create surfaces that are different in color, texture, and form

16. See A. SNYDER, WIIDERNESS AREA MANAGEMENT, U.S.D.A. AdMINISTRATtVe STUdY of REgION 5, Forest No. 101 (1960); Stone, Preserving Vegetation in Parks \& Wilderness, 150 SCIENCE 1261-67 (1965).

17. A discussion of human impact on natural sites may be found in A. Magill \& E. Nord, An Evaluation of Campground Conditions and Needs for Research (U.S. Forest Service, Research Note PSW-4, 1963).

18. For an introduction to land-use planning from an environmental point of view see I. McHarg, Design with NATURe (1969).

19. In the following discussion, it is possible only to toueh upon the more obvious and first order impacts, with long-term or chain-reaction effects left largely to speculation.

20. See L. Leopold, Hydrology for URban Land Planning (U.S. Dep't of the Interior Geological Survey Circular No. 554, 1968) (a guide-book on the hydrologic effects of urban land use). 
-with striking visual results. ${ }^{21}$

Major fill operations disturb down-canyon air flow and create fog pockets. Major cuts, by exposing vegetation to strong winds and blowdown, and to the sun and dryness, may change the natural plant community. ${ }^{22}$ Clearing of vegetation affects plant communities, and, in turn, the wildlife habitat. ${ }^{23}$ Similarly, landscape plantings may affect native vegetation, insect populations, and wildlife. Trenching can cut off ground water flow to downslope vegetation. ${ }^{24}$ Paving can increase and speed rainwater runoff, cause erosion, accentuate flood peaks, and, later in the season, result in dryness and higher temperatures which can affect plant life and human comfort. ${ }^{25}$ Finally, fencing affects big game feeding and other wildlife behavior, and, consequently, the natural vegetation is affected as when ungrazed grasslands grow up in brush. ${ }^{28}$

\section{Logging}

Timber harvesting commonly involves a change in natural vegetative patterns in favor of commercially useful types, sometimes at the expense of varieties of trees, shrubs, and micro-flora. Tree-related insects and diseases are hindered through the removal of dead and susceptible trees, or encouraged as in the case of root rot spreading through stumps and root systems left from logging. ${ }^{27}$ Logging debris or slash is also produced; which causes air pollution if burned, affects the soil if buried, and may result in fire hazard and debris that may be visually objectionable to many if merely left on the ground. ${ }^{28}$

Logging commonly results in soil exposure, removal, or compaction, which may produce erosion, stream sedimentation, and visually prominent scarring. Soil fertility, permeability, water-holding capacity, and seed germination capacities can be positively or negatively affected. ${ }^{29}$

21. See R. Litton, Jr., Forest Landscape Description and Inventories (U.S. Forest Service Research, Paper PSW-49, 1968).

22. See S. SPURR, Forest ECOLOGY (1964).

23. See R. TRIPPENSEe, WIIDLIFE MLANagement (1948).

24. See R. Linsley, M. Kohler, \& J. Paulfus, Applied Hydrology (1949).

25. See L. LeOPoLd, supra note 20.

26. McBride \& Heady, Invasion of Grassland by Buccharis pilularis D.C., $21 \mathrm{~J}$. RANGe MANAGEMENT 106-08 (1968).

27. For descriptive material on logging and insect and disease control see Wygent, Insect Disease Control Composite, Case No. 10, in U.S. DEP'T of CoMmerce, Public Land Policy and the EnVIronment, Part II, Study of Environmental ProbLEMS on THE PUblic LaNDs (R. Hansen ed. 1970) (prepared for the Public Land Law Review Comin'n) [hereinafter cited as Environmental Problems on the Public LANDS].

28. See R. LuCAS, Visttor REACtIon to TIMber HaRvesting IN the Boundary Waters Canoe Area (1963). See generally I. Burton \& R. Kates, Readings in ResourCe MANAGEMENT \& CONSERVATION (1965).

29. See Beckimg \& Hayes, Cutting Practices Composite Case No. 7, in ENvironmental Problems on the Public Lands. 
Insect control to protect commercially valuable timber has involved aerial spraying of pesticides. This obviously las important implications not only for fisl and wildlife, but also for insect predators and the natural population of insects that are not forest pests. ${ }^{30}$

Temporary reduction or long-term alteration of vegetative cover can influence snow pack accumulation and persistence, and the amount and timing of water runoff. Hence, the water supply may be affected, and flooding or drought conditions accentuated..$^{31}$ Wildlife habitat may be changed to the advantage of some species and to the disadvantage of others. ${ }^{32}$ Wildlife population size, diversity, and patterns of daily movement and migration are thus influenced.

Logging also may have adverse affects on water and water sports. Logging in stream channels and edges can cause erosion and destruction of sport fish habitats; ${ }^{33}$ and if shading vegetation is removed, the water's teinperature may be increased and its oxygen lolding capacity reduced. ${ }^{34}$

\section{Recreation Use}

Recreation inay have the effect of preservation or may produce significant adverse impacts. Since recreation development often takes place on highly valued, rare, or delicate sites, as well as in the "ordinary" landscape, it often has a negative environmental impact. ${ }^{35}$ Clearing for ski runs and lifts frequently produces both erosion and visually prominent swaths. Snow-making equipment can require trenching, and lodges necessitate vast parking lots. Even caunping can produce soil compaction, removal of small vegetation, injury to inature trees, vandalism, littering, and public sanitation problems. ${ }^{36}$ Tapping springs for water supply will change the ground water table. Heavily used recreation areas commonly have problems of air, water, and noise pollution. ${ }^{37}$

30. See R. Carson, The Silent Spring 111-12 (1962).

31. See CENTER For RESEARCH IN WATER RESOURCES, EFFECT OF Watershed Changes on Streanaflow (1969).

32. See $\mathrm{R}$. TRIPPENSEE, supra note 23. A habitat change, for instance, unight be to the advantage of deer, but to the disadvantage of woodpeckers residing in "snags."

33. See Becking \& Hayes, Pass Creek; Roseburg District of Oregon, Case No. 9, in Environmental Problems on the Public lands

34. See A. Levno \& J. Rotacher, Increases in Maximum Stream Temperatures, U.S. Forest Service, Research Note PNW-65, Oct. 1967.

35. See R. Gibbens \& H. Heady, The Influence of Modern Man on the Vegetation of Yosemite Valley, U.C. Agricultural Experiment Station Manual No. 46, July 1964; Treichel, Yosemite Valley, Case No. 15, in Environmental Problems on the PUBLIC LANDS.

36. See J. Wagar, The Carrying CapactTy of Witd Lands for Recreation (Soc'y Am. Foresters, Forest Sci. Monograph No. 7, 1964).

37. $1 d$. 
Impacts are also produced by more remote recreation uses. Wilderness use can destroy delicate meadows through trampling and overgrazing by pack animals. ${ }^{38}$ Small stands of trees at high elevations can be diminished from use as firewood. This would seem trivial except that in alpine environments growth rates are so slow that natural replacement can take many hundreds of years. ${ }^{39}$ Off-the-road vehicle use, which is rapidly increasing ${ }^{40}$ brings with it such potential impacts as noise, damage to vegetation, and erosion. Motorcycles, four-wheeldrive vehicles, and snow vehicles can disturb wildlife.

\section{Grazing}

Grazing commonly involves controlled burning and the use of herbicides and pesticides. In addition, conversion of timber or brushlands to grassland may produce soil erosion, and improperly managed grazing can also lead to stream or lake side erosion. If properly managed, grazing can contribute to the maintenance of a pastoral landscape; ${ }^{41}$ concentrations of livestock, as in feedlots, however, can result in the flow of substantial nutrients added to streams. ${ }^{42}$

\section{Forestry Operations}

Forestry operations involve a wide variety of impacts. Use of herbicides and pesticides have ramifications for wildlife and human health. ${ }^{43}$ Fire prevention and control, aside from the intended protection of timber and developinents, also has the effect of diminishing those plant and animal populations which were part of the natural ecology of which fire was a part. Fire prevention can lead to an accumulation of dense brush and undergrowth which may be more destructive when fires do occur than they would liave been had there been frequent, natural fires which kept fuel accumulation low. ${ }^{44}$ Tree

38. A. SNYDER, supra note 16.

39. See id.

40. See Miller, Off-Road Recreational Vehicle Composite, Case No. 16, in ENvironmental Problems on the Public Lands.

41. R. Gibbens \& H. Heady, supra note 35; McBride \& Heady, supra note 26; Treichel, supra note 35 .

42. A sinall increase in materials rich in elements basic to nutrition (such as phosphorous or nitrogen) may beneficially increase the amount and variety of plants, insect, and fish life-for example, produce more and larger game fish; however greater amounts of nutrients or sinall increases in water that is already "rich" can lead to the choking of waterways by plant growth, and algal "blooms" which exhaust oxygen supphies and kill fish life.

43. Wygent, supra note 27.

44. See Biswell, Fire Ecology Composite, Case No. 8, in Environmental Problems on the Public Lands; Hartesveldt, The Fire Ecology of the Giant Sequoia, NATURAL HISTORY, Dec. 1964, at 12-19. 
planting, thinning, and other silvicultural practices which favor a few commercially valuable species or produce even-aged stands of trees deserve further scrutiny from an environmental vantage point than can be given here. Forests thus treated may be more productive, but also more susceptible to insects and disease, than are mixed natural stands in which variety and complexity provide stability in the ecosystem. ${ }^{45}$ Finally, on the production end of the spectrum, lumber mills burning waste wood and sawdust are a source of air pollution; pulp and paper mills are a source of air and water pollution, deserving of the most careful consideration in making environmental impact analyses.

\section{Water Resource Developments}

Water resource developments, such as reservoirs, have a myriad of consequences which include inundation, stream flow regulation, water temperature change, evaporation, and the interruption of fish migration. ${ }^{46}$ Smaller scale developments, such as steam diversions or water wells, are also of importance; for example, in depleting ground water necessary to the sustenance of meadowlands, bogs, or swamps, and in turn the elimination of wildlife. Less obvious impacts are found in such watershed managenent practices as fire protection, rehabilitation, stream bank stabilization, and soil conservation treatments.

\section{Mineral Exploration and Development}

Mineral exploration and development, such as prospecting and claim staking that requires excavations to inark or hold a claim, can produce soil erosion and visual scarring. The disposal of mine tailings and overburden presents probleins that are even larger in magnitude, though less widespread. ${ }^{47}$ Because mining is frequently done in difficult terrain, road and utility access can be more significant in terms of impact than the mines themselves.

\section{The Importance of Site Conditions}

The nature and extent of environmental impacts created by various activities often depend on the type of site on which the activities are carried out. Thus, site analysis is also critical. ${ }^{48}$ Environmental con-

45. For a discussion of the value of diversity in an ecosystem see Leigh, On the Relation Between Productivity, Biomass, Diversity, and Stability of a Community, 53 ProceEdings NAT. ACADEMY SCI. 777-83 (1965).

46. See Hungerford, Middle Snake River Projects, Idaho Case, No. 13, in ENvironmental Problems on the Public Lands.

47. See Ferchau, Henderson Project, Colorado, Case No. 3, in Environmental Problems on the PUblic Lands.

48. The subject of site conditions as a consideration in development and planning is treated generally, and with case examples, in I. McHARG, supra note 18. 
ditions differ greatly, not only between regions, but often with minor changes in elevation or place. For example, in the distance of one mile, a mountain road might traverse a meadow and stream, ${ }^{49}$ hard granite, ${ }^{50}$ and decomposed gramite. ${ }^{51}$ Each environmental factor-topography, geology, soil, hydrology, vegetation, wildlife, climate, and visual formhas a varied response to, or capacity for, a particular use or development.

Topography ${ }^{52}$ is related to climate, and in turn, to sensitivity of plant and animal communities. ${ }^{53}$ In the Northern Hemisphere, northfacing slopes tend to be wetter, cooler and shadier than ones facing south. ${ }^{54}$ Hence, in dry areas, such as the American southwest, disturbed areas on south slopes are more difficult to revegetate due to chmatic stress. South-facing slopes are more highly visible, because the sun's angle provides front lighting. ${ }^{55}$ Steep slopes usually present more development side effects than do flatter ones, as the force of gravity operates against stability, and accentuates problems of rock movement and soil erosion.

Geology determines the ease of grading and workability, propensity to slide or slump, and the amount of silt, sand, gravel, rocks, or boulders deposited in streains when the surrounding area is disturbed. In addition, underlying rock materials react differently to earthquakes: some are firm, some shake like a bowl of jelly, others subside, crack, or fall. ${ }^{50}$ Thus, earthquake hazard is a function of the rock material of the site as well as a function of the distance of the side from the quake epicenter.

Hydrology also presents important considerations. Depending on

49. Where construction on pilings might be sought to minimize disturbance of surface and ground water flow.

50. Which may necessitate blasting.

51. Where strong erosion control measures will be needed.

52. For an analysis of typical landforms in the United States sce J. Scover, ATLAS OF LANDFORMS (1965).

53. For instance, for a given type of plant, climatic conditions related to elevation will be one determinant of stress. In alpine areas, higher elevations have generally more exposure to severe low teniperatures, and shorter growing seasons. In deserts, low elevations would be associated with extreme high temperatures, and low humidity. With an understanding of tolerances and stress, one can better assess the capability of an organisin or community to maintain itself in the face of (or recover from) disturbance.

54. The importance of slope and aspect are treated generally in K. LYNCH, SrTE Planning (1962).

55. R. Litton, Jr., supra note 21 , in discussing the visibility of disturbances, such as logging skid trails or road cuts, points out that because of front highting, details on south facing slopes can be viewed in greater detail, and color contrasts-for example, exposed red soil against a green forest canopy-are more striking than is the case on shaded northern exposures.

56. See generally R. LEGGET, GEOLOGY AND ENGINEERING (2d ed. 1962). 
watershed configuration, land use, size of the stream, elevation drop and other factors, streams differ greatly in their capacity to handle sediment and flood waters. ${ }^{57}$ Water amounts, temperature, depth, and currents vary the capacity of streams, lakes, roads, and aquifers to absorb nutrients and pollutants. ${ }^{58}$

Soil conditions can vary the effects of given activities. Soil responds to impact in proportion to such factors as depth, sheet erosion characteristics, slope, vegetation, water content, fertility, and profile. ${ }^{60}$ For example, the surface soil might tend to absorb impact, yet a subsurface layer of clay may cause ecological problems such as land slippage or accumulation of salts or pollutants near the surface. ${ }^{69}$

Vegetation may be quite stable, reconstituting the natural plant commumity quickly after disruption; or, as in certaim desert environments, alpine meadows, tundra, estuaries, swamps, and lagoons, shight changes may trigger successive ecological reactions. Even within each vegetation type, impact response varies as to age of the vegetation, fire history, wildlife population, climate, and history of land use. ${ }^{61}$

Wildlife's response to impact is even more difficult to assess. The impact depends on such factors as the number of different species involved, population sizes and trends, food and cover requirements, predator-prey relations, migration routes, and tolerance for noise and disturbance. ${ }^{62}$

Climate affects the weathering of rock, soil formation, erosion, and capacity for vegetative cover. Areas differ in capacity to disperse air pollution, depending on such variables as air shed configuration, temperature regimes, and local winds. Development impacts are not only sensitive to average rainfall and temperature conditions, but to the timing, frequency, and intensity of heavy storms, and local variations in wind, temperature, and snow pack accumulation. ${ }^{63}$ Hence, on-site studies are normally required to identify problem areas such as fog pockets, flood plains, or avalanche hazard zones.

Coastal and marine environments present similar composites of shore characteristics (cliffs, dunes, or mangrove swamps), bottom configuration and material (be it sand, mud, rock, or coral), water condi-

57. R. LINSLEY, M. KOHLER \& J. PAULhUS, supra note 24.

58. See generally F. Ru'TTNER, supra note 14.

59. See generally L. Bartelli, SoIl SuRveys and LaNd Use Plannino (1966).

60. See Reiske, Soil Landscapes, An Index to Multiple Use, 64 J. Forestry 230 (1966).

61. See R. Daubenmire, Plant Communities: A Textbook of Plant SynECOLOGY (1968).

62. Leopold, Cain, Cottam, Gabrielson, \& Kimball, Wildlife Management in the National Parks, AM. Forests, Apr. 1963, at 32.

63. See R. Geiber, The Climate Near the Ground (1966). 
tions (depth, clarity, temperature, salinity, currents), and the composition of aquatic life. ${ }^{64}$ Because the coast represents an interface between terrestrial and marine ecosystems, environmental planning must be based on an understanding of each system in isolation, and in addition, upon relationships between the two. Thus, the planning tasks are more formidable.

Finally, visual and spatial conditions-configuration and volume of space, lighting, color and texture of surfaces, distances and scope of important views, and so on-merit separate consideration. ${ }^{65}$ For example, a major highway might, with adequate pliysical and biological controls, blend into one canyon, yet physically dominate another, be screened from view in dense forest, but be visually prominent in open country.

Froin the foregoing brief survey it should be apparent that predicting and controlling a development's impact on the environment will require detailed information both as to the development's physical and engineering characteristics, and also the environment's composition as to topography, geology, soil, and other factors. A successful land management system would be, therefore, one which is equipped to collect, evaluate and make decisions based upon this inforination.

\section{II}

\section{CRITERIA OF ENVIRONMENTAL MANAGEMENT}

\section{A. Definition of Terms}

\section{Environmental Quality}

Environmental quality, as used here, means primarily the continuance, to the extent feasible, of the natural ecosystem existing on public lands, especially as that ecosystem is important to human health and safety, the provision of direct sensory experiences, and the continued viability of life forms and biotic commumities that exist naturally on, and surrounding, the public lands in question. Obviously, the use of public lands for products and services will change the ecosystem and, hence, environmental quality, can never fully be maintained. It is possible, however, to determine the extent of agency concern to minimize such changes in the course of development, and agency mechanisms for understanding, predicting, and controlling the harmful impacts on the ecosystem generated by its commodity and service activities.

64. See generally W. BASCOM, WAVES AND BEACHES (1964); E. RICKETS \& J. Calvin, Between Pacific Tmes (1952).

65. R. Litton, Jr., supra note 21. 


\section{Environmental Management}

We use the term environmental management to indicate a system that generates knowledge of environmental and ecological impacts, and evaluates their consequences before activities are undertaken. Impact assessment, used at this point of the process, may lead to the rejection of a land use or the allocation of land to a particular safe purpose, amelioration of predicted effects, or replacement or restoration of damaged components of the ecosystem.

\section{B. The Focus of Analysis}

Determination of the adequacy of an agency's system of environmental management requires an analysis of the statutes, regulations, directives, cooperative agreements, and other legal documents under which the agency operates. It also requires an analysis of the agency's level of funding, the number and training of its personnel, and field observation of its performance. This analysis seeks to evaluate seven factors: one, the authority and responsibility of the agency to control environmental impacts of activities carried out on its lands; two, the nature of the planning and management systems used for these purposes; three, the mechanisms that exist for cooperation with other agencies; four, the nature of the policies that have evolved within the agency relating to environmental protection; five, who carries these policies out under whose supervision; six, the systeins for inspection and enforcement; and seven, the opportunities presented for public participation in decision making. ${ }^{66}$

\section{An Ideal System of Environmental Management}

An ideal system of environmental management would be based on statutory authority and responsibility to protect environmental objectives - for example, preservation of air and water quality, wildlife and scenery-as well as to fulfill production and use objectives-timber,

66. The seven categories of the proposed analysis assure the existence of administrative agencies that are responsible for carrying out federal legislative and executive policies respecting the manageinent of the public lands. The categorics are designed to encompass all the relevant steps in the administrative process-from the statute creating the anthority and responsibility through the provisions for public participation in agency decision-making. The approach is that of the lawyer, planner or administrator who is interested in authority and institutional processes. Sociologists or economists, to name just two disciplines, might well use different organizing principles.

The proposed analysis also assumes that most public lands will continue to be used for the production of goods and services. The process of environmental management that is urged, however, night result in the curtailment of such production when the environmental cost is too high. A recurring criticisin developed in this Article is that many production activities are undertaken without any realistic idea of what environemntal costs are being incurred. 
minerals, recreation and the like. To accomplish this, the planning and management system would produce information necessary to anticipate environmental hazards, including detailed geological and soil surveys, research and site investigations. The system would require that new data be acquired for new decisions, as well as the use of available data. Information would be valid as to scale; small-area, sitespecific studies would be employed as well as general surveys. Difficult problems would be solved through detailed investigation, experimentation, simulation, and monitoring.

The pace of the planning process would allow time to gather, analyze, and interpret environmental data before plans crystallize. There would be clear environmental objectives, and more importantly, these would be translated into specific criteria with measurable and achievable standards. Land-use or functional planning would incorporate environmental variables.

Coordination and cooperation with other agencies-federal, state, local, and private-would extend to setting environmental objectives, anticipating impacts, collecting and evaluating data, and reviewing alternatives. Coordination would relate to environmental interactions and externalities by functional areas-for instance, air-sheds, watersheds, and migratory game ranges-and not just with regard to adjacent property or the efficient provision of a limited commodity such as recreation. Moreover, the management agency would be charged with responsibility to take actions outside of its property boundaries in order to control both adverse effects that occur there, for example downstream or down slope, and also secondary ecological reactions, such as destruction of salmon spawning areas due to sediment from road construction.

Personnel involved in environmental planning would include specialists such as geologists, engineering geologists, hydrologists, soil scientists, plant community ecologists, wildlife biologists, water quality engineers, climatologists, archaelogists, as well as tramed resource management professionals such as foresters or range managers. Team action or other procedures would be used to insure comprehensive assessment of potential environmental problems, plus opportunity for individual work in depth on specific problems related to proposed development or land use.

Funding would provide for long-term, broad-coverage background information, for long-term experiments and simulations, and for project-associated impact studies. Funds for inventories and experiments would be continuing and fairly stable. Impact study funds would expand ahead of, or at least concurrently with, increases in investment in developments. An agency would also provide efficient 
means for evaluating, supervising and inspecting its own activities and those of permittees and other users. This would include automatic inonitoring devices as well as site visits. Finally, the agency's procedures would be hospitable to public participation in setting environmental objectives and standards, the evaluation of project impacts, and the review of environmental impact assessments made by it and other agencies.

With this ideal system in mind, it is possible to examine the Forest Service system for coping with environmental problems associated with timber harvesting. The examination begins by describing the overall planning and management system of the Forest Service. Since timber management is but one sub-system of Forest Service activities, its environmental implications can be best grasped if the reader understands something about the broader system.

\section{III}

\section{THE FOREST SERVICE: OVERVIEW}

The Umited States Forest Service, an agency of the Department of Agriculture, administers nearly $187,000,000$ acres of land. ${ }^{67}$ The chief's office in Washington, D.C., directs the activities of nine regional offices. $^{68}$ The nine regions are divided into 154 national forests. ${ }^{00}$ These, in turn, are subdivided into 790 ranger districts. ${ }^{70}$ There are also a number of research and cooperation-oriented units, including eight regional experiment stations. ${ }^{71}$ The work of the Forest Service is essentially three-pronged: Management of the natural resources within national forests and national grasslands; research into all aspects of forest management; and proinotion of sound conservation and utilization practices among the states and all private forest landowners through cooperation, research, and dissemination of information. This article is coneerned with management and research.

The Multiple-Use and Sustained Yield Act of $1960^{72}$ recognizes that the national forests are to be administered primarily for outdoor recreation, range, timber, fish and wildlife, and watershed. The statutory charge calls for:

the management of all the various renewable resources of the national forests . . . utilized in the combination that will best meet the needs of the American people-consideration being given to the

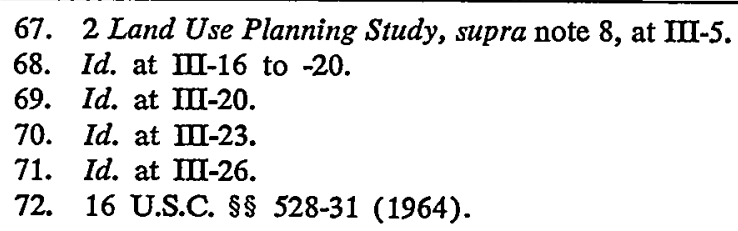

67. 2 Land Use Planning Study, supra note 8, at III-5.

68. Id. at III-16 to -20 .

69. Id. at III-20.

70. Id. at III-23.

71. Id. at III-26.

72. 16 U.S.C. $\$ \S 528-31$ (1964). 
relative values of the various resources, and not necessarily the combination of uses that will give the greatest dollar return or greatest unit output. ${ }^{73}$

This open-ended direction requires a complex system of multipleuse planning and management that will set priorities and will constantly provide for optimal mixtures of resource and use activities that provide for productivity, sustained yield, and environmental health. ${ }^{74}$

73. Id. $\& 531$ (a). The five purposes do not, however, define all the uses that are made of these lands. They are also subjected to potentially incompatible activities such as mining exploration and exploitation, power lines, road and highway building, and water projects over which the Forest Service often has difficulty in exerting effective control.

74. The Forest Service, consistent with the increasing sensitivity of the federal government as a whole, is exhibiting heightened concern with environmental impacts resulting from activities on its lands. This is illustrated by recent policy statements made at various administrative levels.

The Chief's Nationwide Objectives for Fiscal 1971, for instance, provide eleven objectives, many of which are concerned with environmental protection. The key one is to "[p]rotect and improve the quality of air, water, soil, and natural beauty." Quoted in U.S. Dep't of Commerce, Public Land Policy and the Environment, Part I, The Legal and Administrative Framework for Environmental ManageMENT III-2 (1970) (prepared for the Public Land Law Review Comm'n by I.M. Heyman \& R. Twiss) [hereinafter cited as ENvironmental ManhGement STUdy]. A number of policies are offered to this end:

Promote enviroumental quality, including natural beauty, im management of all forest ownerships.

Demonstrate high standards of management throughout the National Forest System. Recreation and range uses, timber harvesting, road construction and other resource developinent and use activities will be conducted so as to protect land and resource quality and productivity.

Encourage prevention or abatement of pollution from forestry-related enterprises.

Proinote management actions to reduce adverse impacts on offsite environments affected by all forest ownerships.

Id. While other objectives are not exclusively concerned with enviroumental protection, some of the policies stated for their fulfillment are of close concern. For example, the general objective of promoting and achieving a resource use pattern that will "best meet the needs of the American people now and in the future," [id.] though oriented mainly to resource productivity, is accompanied by a number of environmental policies, including:

Give special emphasis to rare and endangered plants and to significant examples of ecological, archeological, geological, and historic interest.

Promote high quality wildlife and fishing habitat to ensure a mixture of types and numbers for public benefit. Special emphasis should be provided to protect rare and endangered species of native animals, fish, and birds.

Id. The einphasis on environmental protection has had a clear impact on policy formulation at lower administrative levels as well. Regional objectives for the California Region stated in the Regional Forester's Program of Work (fiscal year 1971), for instance, contain one item devoted exclusively to enviroumental quality problems:

Environmental Improvement

Protect and enhance the quality of air, water and natural beauty. Insure that every Forest Service and permitted use conforms to or exceeds minimum State and FWPCA standards. Place imto effect a sound landscape mauagement program. Conduct all programs in a manner that will create the least possible amount of permanent damage to resource quality and productivity. Get 
The Service's multiple use planning and management system calls for the preparation of a series of plans and reports which zone land, state measures needed to coordinate different uses, and propose particular projects and activities to carry out each of the major Forest Service missions. The major documents of relevance, explored below, are the Regional Multiple Use Management Guide (Regional Guide), ${ }^{75}$ the District Multiple Use Management Plan (District Plan), ${ }^{76}$ resource and activity management plans, ${ }^{77}$ multiple use impact surveys, ${ }^{78}$ and action plans and action programs.

\section{A. Regional Guides}

Within the framework created by Service directives, advance land planning occurs at three levels: regional, forest, and district. At the first, each region prepares one or more Regional Guides in order to survey certain demand and supply data, review management situations, and state basic assumptions for various resources and activities within the region. Regional Guides contain general coordinating requirements designed to prevent or minimize specific resource conflicts, de-

other groups and agencies to avoid or abate pollution from related enterprises. Working within research, develop new methods to reduce pollution resulting from using fire in land management practices.

ENVIRONMENTAL MANAGEMENT STUDY III-3. Other items treat particular environmental aspects, often in great detail. The following, for example, is extracted from the Soil and Water objective:

Refine and supplement present inventory data on watershed rebabilitation needs. Prepare restoration plans for areas by Regional priority. Develop standards for soil loss levels of acceptance for each functional land management activity. Develop and implement a system of monitoring water quality to protect the water resource from possible damage resulting from land management activities. Where needed, give top priority to stabilization of exposed soils, especially burned areas. Develop economic systems evaluation procedures which will provide resource managers with a form of output data usable for evaluation of watershed treatment projects. Protect National Forest rights for water needed to meet resource and management needs. Require performance bonds where there is a recognized need to protect soil and water resource from damage by permittees or licensees.

Id. Part III of the Regional Forester's Program of Work outlines goals for fiscal 1971. This is a quite lengthy document which enunciates 77 separate goals and assigns responsibility for them to particular divisions and, where appropriate, to specific National Forests. A great number of these goals are aimed, in part or in whole, at problems of environmental quality and protection. $1 d$.

75. U.S. Dep't of Agriculture, Forest Service Manual fIt 2120-24 (1970) [hereinafter cited as F.S. MANuAL]. The framework for the Forest Service's directive system is provided by statutes and regulations. The Forest Service Manual, issued by the chief's office, contains the principal directives for the agency. In addition, the various regional offices publish Supplements to the Manual containing more detailed directions applicable to the forests within the region.

76. Id. ๆก 2130-34.4 (1967).

77. Id. กा 2400-96.6 (issued at various dates). An example of a resource and activity management plan is the Timber Management Plan.

78. Id. โा 2140-41.4 (1963). 
fine geographic management zones, ${ }^{79}$ and state additional coordinating requirements for specific resource and use activities applicable within such zones.

\section{Management Situations, Basic Assumptions and General Coordi- nating Requirements}

Statements in Regional Guides addressed to environmental considerations largely indicate regional concern and present gross statements of problems and opportunities together with eclectic collections of common-sense measures that ought to be undertaken to cope with environmental problems. ${ }^{80}$ They are not rigorous; they are not based

79. Typical zones, exemplified by those used in Intermountain Region, include the "crest zone," "intermediate zone," "lower zone," "water influence zone," "travel influence zone," and "riverbreak zone." Iverson, Foreward to U.S. Dep"t of Agriculture, Forest Service Handbook, Multiple Use Management Guide, Intermountain Region ch. 000-03, Dec. 1965 (FSH 2121.4).

80. The following excerpts addressed to "natural beauty," illustrate the typical generality of the statements.

Resource Potential. The Southwestern Region is rich in natural attractions and pleasing landscapes ranging from high alpine meadows to desert. There are deep canyons, large forested plateaus, numerous exposures of spectacular geological formations, and an abundance of archeological treasures. Many plants and animals in all life zones make natural beauty one of the outstanding attractions of the Region.

In 1965 , about 19 percent of the total recreation use in the Southwestern Region was devoted to viewing scenery, enjoying umique or unusual environment, and in pleasure driving. We can expect this use to increase sharply in the future.

Basic Assumptions

1. Natural beauty is Regional in scope

2. An increasing number of people will use National Forest System lands to enjoy the scenery.

3. Managennent activities can affect the beauty of the land.

4. Natural beauty cau be maintained and enhanced on National Forest Systein lands in the management and utilization of the resources.

Management Objectives

1. Recognize natural beauty and seize opportunities to protect or enhance it in all activities conducted on National Forest System lands.

2. Give special recognition to attractions of National significance, such as the red rocks near Sedona.

3. To the extent feasible, construct roads and trails in a way that will display special landscape scenes and outstanding natural attractions to the people who use them.

4. Merge roads, trails, and other man-made structures into the landscape as much as possible.

General Coordinating Requirements [to enhance natural beauty aud to be considered in every resource undertaking (e.g., designing a timber sale)]

-..

4. Recognize natural beanty as a resource and to the fullest extent possible manage all activities to retain or enhance its qualities.

5. Recognize and protect scenic views visible from major travel routes.

6. Control "throw down" camping to the extent necessary to prevent serious damage to other resources, uses, and activities.

7. Protect or enhance potential recreation sites and access thereto.

Id. Southwestern Regions chs. 113, 211, Aug. 1967. 
on detailed data; and they are not comprehensive.

\section{Management Zones}

The Regional Guide also sets forth a geophysical framework of management zones that defines areas of homogeneous environmental and policy problems. The zoning texts describe, generally, what lands the zones are to contain. Attendant coordinating requirements for each zone-common-sense prescriptions for resource protection-are also stated. The zoning is based primarily on physical factors and the prescriptions are normally quite general. ${ }^{81}$

\section{B. District Plans}

The second level of advance planning occurs in the ranger district. The Regional Guide sets forth general guidelines for the District Multiple Use Management Plan prepared by the district ranger with the as-

81. This can be illustrated by the following excerpts from the Southwest Regional Guide:

Crest Zone

The Crest Zone is composed of high elevation areas with predominantly alpine and subalpine vegetation. Elevations range from 10,500 feet with some of the higher ridges and peaks above timberline. The lower zone boundary is the upper edge of the commercial types.

The Crest Zone is relatively small-containing less than 10,000 acres. It is characterized by high rugged rocky ridges, small streams, meadows, and limited stands of subalpine trees. Common species are subalpine fir, dwarfed Engelmann spruce, and limber pine. These trees are slow growing and of noncommercial quality. Occasional subalpine basms with perennial grass forbs occur in this zone.

Severe climatic conditions, characterized by short growing seasons, variable temperatures, and thin tundra soils result in low forage production. The zone furnishes summer habitat for wildlife and a small amount of forage for livestock.

Average annual precipitation is above 30 inches and mostly in the form of snow. The Crest Zone furnishes the greatest water yield per acre in the Region.

Annual water yield ranges from about $1 / 2$ to $21 / 2$ acre-feet per aere.

Fishing and hunting opportunities are limited due to the size of the zone. It furnishes outstanding scenery and is a favorite area for dispersed recreation. The zone has potential for winter recreation activities in the more accessible areas.

Management emphasis will be directed towards protection and improving water quality while safeguarding and enhancing natural beauty and aesthetic values for back country recreation. Use of the Crest Zone for electronic sites will be carefully weighed against the effect of such developments on the natural beauty and water yield.

Coordinating Requirements

1. Prevent soil disturbance and uses that will adversely affect the hydrology of the land.

2. Recognize in all uses and activities the adverse effects from run-off associated with high water yield.

3. Protect watershed values and natural beauty by allowing only essential structural developinents.

Id. ch. 310 . 
sistance and approval of the forest supervisor. The District Plan maps the zones provided in the Regional Guide and sets forth a series of management decisions which seek to coordinate resource and use activities to be carried on within these management zones. Occasionally, the District Plan further delineates "management units" — sub-areas within zones that are devoted to particular uses, such as range allotments for grazing, or are particularly vulnerable, such as geologic slide areas. ${ }^{82}$ Management decisions-for example, maintain maximum conditions for the deer population in cutting timber-are to be applied both to assure needed coordination in devising the various resource and activity management plans and also to fashion action plans and action programs. Both the Regional Guide and the District Plan seek mainly to coordinate different resource and use activities so that one is not undertaken in a manner avoidably deleterious to another. Coordination, however, has important environmental consequences. The decisions that are made at the district level occasionally convert regional coordinating requirements into absolute prohibitions against certain harmful uses or activities in the zones. ${ }^{83}$

The District Plan is intended to make more specific, in content and location, the more general statements contained in the Regional Guide. Often, however, the Plan's prescriptions are no more specific. Moreover, they too are rarely based on the types of rigorous investigation that produce detailed ecological data.

\section{Functional Plans}

The third level of advance planning is normally carried out at the national forest level. This involves the preparation of management plans for particular resources and uses by staff specialists in concert with district rangers. Such plans include: timber management plans, recreation management plans, wildlife habitat management plans, range allotment management plans, land adjustment plans, watershed management plans, fire control plans, and transportation plans. ${ }^{84}$

82. See note 109 infra.

83. For example, the Pine Ridge District Plan [U.S. Dep't of Agriculture, Forest Service Handbook, Multiple Use Management, Pine Ridge District Multiple Use Plan, Central Plains Forestry Office, Nebraska National Forest, Rocky Mountain Region ch. 373, Jan. 1965 (FSH 2-2131.4)] prohibits the digging of borrow pits or dumping of garbage in Water Influence Zones; the Snake River District Plan [U.S. Dep't of Agriculture, Forest Service Handbook, Multiple Use Management, Snake River Ranger District Multiple Use Plan, Medicine Bow National Forest, Region Two ch. 373, Apr. 1967 (FSH 2121.4)] forbids grazing during periods of heavy recreational use and limits mining locations in the Water Influence Zones. Explanations for suggested actions or prohibitions of actions are rarely offered by the Manual, Regional Guides, or District Plans, though they are often apparent.

84. I Land Use Planning Study, supra note 8, at III-84, III-99, III-123, III-144, III-160, III-176. 
Management plans provide the basis for action plans and action programs. Generally, they list targets to be achieved and criteria to guide operating personnel in decisions specifically relating to the resource or activity in question. Impacts on other resources are also considered in fashioning these plans. One set of restraints is stated in Forest Service Manual sections related to each of the functions and activities for which management plans are prepared. ${ }^{85}$ These restraints, known as coordinating instructions, are applicable to the entire national forest system in addition to the coordinating requirements discussed above. Management plans often contain specific plans for particular areas within the national forest.

These functional plans, ideally, are tied to one another through the Regional Guides and District Plans which are intended to provide a franework for their preparation. ${ }^{86}$ Often this is not the case, however, and the District Plan, especially, becomes primarily a device to record where within the district the activities established by the functional plans will occur ${ }^{87}$ Blatant use and activity conflicts can still be spotted and ameliorated, of course, but more subtle conflicts are not discovered until quite late.

\section{Action Planning and Multiple Use Impact Surveys}

The action plan is the final phase of resource or activity management planning. It contains detailed directions for the intended action taking into account inpacts on other resource uses and activities. The action plan prescribes how and when resource and activity management and development will be accomplished. Action plans, prepared at the ranger district level, include: timber sales plans, road layout plans, pernnittee range allotunent management plans, erosion control plans, and slash disposal plans. ${ }^{88}$

The Multiple Use Impact Survey and Report is a prerequisite to

85. For instance, title 2600 of the Forest Service Manual deals with wildlife management. Chapter 2606.1 sets forth a series of instructions for coordinating wildlife managennent with other resources and uses including range, recreation, timber, and watershed. There are four coordimating instructions concerning timber. As an exainple, the first of the four states: "Endeavor to prevent excessive animal damage to crop trees on areas managed primarily for timber prodnction. In establishing carrying capacities for big game species, consider browsing damage to forest reproduction as well as maintenance of browse food snpplies." F.S. MANUAL, supra note 75, 12606.13 (1968).

86. 1 Land Use Planning Study, supra note 8, at I-17.

87. See id. at III-46 to -61 .

88. Each of these, and others, is described in the Forest Service Manual and, usually, in supplements prepared at the regional level. See, e.g., F.S. MaNunI, supra note 75, โी 2417 (timber sale action plan), 2481.21(3) (slash treatment plan), 2214, 2237.11 (range allotment management plans) (1968). 
action planning. It is intended to evaluate a proposed project in detail to determine the precise "harms" that might flow, and whether or not the project is "compatible and suitable with the multiple use nanagement of public lands ...." ${ }^{89}$ The Survey can be a useful tool of environmental management if it is done rigorously and well in advance of the project undertaking. Unfortunately, this is not always the case, especially with regard to small undertakings.

\section{E. Overview of the Research System}

The Forest Service conducts a continuing and substantial program of research, inventory, and analysis, much of which is relevant to environmental considerations. For example, the Pacific Southwest Forest and Range Experiment Station at Berkeley, California, employs approximately 100 scientists and semior professionals. ${ }^{90}$ Studies are conducted on a wide variety of land management problems, often in connection with the administrative branch of the Forest Service, with other federal, state, and local agencies, and with unversities. Some of the work is primarily oriented to commodities. This category would include genetics research on commercially valuable tree species that are disease-free and watershed management experiments which test ways for providing increased amounts of irrigation water. Increasingly, however, research is being focused on environmental issues. ${ }^{91}$

In the main, research is directed, staffed and funded in relation to problems rather than places. Problems are selected by researchers and research administrators, not forest managers. This autonomy permits freedom of scientific inquiry, objectivity, and a long-range perspective vital to a research program which may take a number of years to produce results. Care is taken to identify and attack those problems which are most critical to land management, but the actual location of study depends on where the problem is nost easily and efficiently examined.

89. Id. II 2140 (1963).

90. Berkeley is one of eight stations nationwide. Forest Service, U.S. Dep't of Agriculture, Pacific Southwest Forest and Range Experiment Station Annual Report, Research Progress 1968, 1969.

91. Current topics include: Team research on remote sensing and forest pathology to detect and evaluate air pollution damage to forests (in cooperation with Public Health Service); evaluation of stream habitat using new inethods of sensing (in cooperation with Trout Unlimited, Pacific Gas and Electric Co., the California Department of Fish and Game, the California Cooperative Fisheries Unit of the Fish and Wildlife Service, USDI, and Humboldt State College); new nethods of analyzing landslide potential and slope stability, so as to avoid problems in logging and road construction; evaluation of campground soil and vegetation problems to determine effects of heavy use; testing of practical anethods for compacting, cutting, and crushing logging slash to enable disposal without burning. See id. 
Problem orientation and problem selection by research personnel create some difficulties in linking research undertakings and outcomes to actual resource problems being experienced by Forest Service managers. When a particular development problem arises in the field, for instance, or when a forest plan or impact study is initiated, there may or may not be relevant research results and background data available. Moreover, interpretation of research falls to the land manager and the valid use of research hinges on his prior training, his currency with the hiterature of professional and scientific journals, and the effectiveness of in-service training sessions and publications including the Forest Service Handbook.

Forest Service scientists are available as consultants to land managers, but the increasing need to specialize in scientific work and the complex and diffuse nature of management problems pose obstacles to collaboration between researcher and manager. While research is progressing on a broad front, there is only limited evidence of any coordinated environmental research program based on a set of environmental priorities. Likewise, there is very little emphasis currently on expansion of basic environmental surveys and monitoring. The role of the research branch in relation to the land managers is unclear, especially in the preparation of location-oriented impact studies.

As the foregoing indicates, there is a gap between study aimed at the solution of immediate management problenis and the conduct of long-range scientific study. Thus basic inventory work and environmental impact assessment-collection of basic data, interpretation by highly qualified, scientist-professionals, and judging environmental impacts--must be handled at the regional, forest, or district levels, and not primarily by the experiment stations which currently possess most of the tramed personnel.

\section{IV}

\section{THE FOREST SERVICE: TIMBER PLANNING AND MANAGEMENT}

By examining timber harvesting, it is possible to describe the legal and administrative framework for planning and management, and to analyze the adequacy of the system to protect environmental values. The discussion looks first at the advance planning level of this system and what of relevance is contained in Regional Guides, District Plans and Timber Management Plans, and then turns to the action phasenultiple use impact surveys, action plans and programs-and the means used to enforce environmental standards. The potentialities of the system are evaluated in relation to the criteria previously set forth for environmental management. ${ }^{22}$

92. See note 66 supra. 
The management and provision of commercial timber resources is a major mission of the Forest Service. Regulations issued by the Secretary of Agriculture require certain specifications in the preparation of timber plans. ${ }^{93}$ The specification primarily important to this discussion requires that timber plans "provide for coordination of timber production and harvesting with other uses of National Forest land in accordance with the principles of multiple use management." 94 To the environmental lawyer, the worth of this specification depends upon the degree to which the Regional Guides, District Plans, Timber Management Plans, and the systems of inultiple use impact surveys, action prograins, permits, and enforcement take environmental problems into account and seek to avoid the creation of environmental harms of the types identified.

\section{A. Advance Planning and Analysis}

\section{Management Situations: Basic Assumptions}

The Regional Guides contain sections offering guidance to rangers and other personnel in managing and coordinating resources and activities. ${ }^{95} \quad$ Every Regional Guide contains a management situation and basic plannimg assumptions concerning timber. While most of these are very generalized statements concerning demand and supply factors, a few identify environmental considerations which are important to the region and should be taken into account in timber management and action planning. ${ }^{96}$

93. 36 C.F.R. $\S 221.3$ (1970) states that the plans are to:

(1) Be designed to aid in providing a continuous supply of national forest timber ... (2) Be based on the principle of sustained yield, with due consideration to the condition of the area and the timber stands covered by the plan. (3) Provide, so far as feasible, an even flow of national forest timber in order to facilitate the stabilization of communities and of opportunities for employment. (4) Provide for coordination of timber production and harvesting with other uses of National Forest land in accordance with the principle of multiple use management, and (5) Establish the allowable cutting rate which is the maximum amount of timber which may be cut from the national forest lands within the unit by years or other periods.

The matters identified in points (1), (2), (3) and (5) of the regulation deal unainly with prodnction of timber under sustained yield practices and there is a large literature dealing with them. E.g., F. BAKer, Principles of Silviculture (1950); K. Davis, Forest MANAGEMENT ( $2 \mathrm{~d}$ ed. 1966).

94. 36 C.F.R. § 221.3 (1970).

95. See text accompanying notes 79-81 supra.

96. For instance, a management situation statement in the Regional Guide for the Intermountain Region provides:

Forests have great values for wood production. They also provide ground cover for watershed protection. Their shade along streambanks keeps water temperatures lower, improving fish habitat. They furnish shelter for wildlife. Forested areas are popular for recreation, and their natural beauty has great scenic value. How forests are managed and used will affect not only future timber yields but also the availability of these other products and services. 
Management situations and basic planning assumptions are often stated for natural resources, such as air, and for activities associated with resource protection, such as fire control, that bear on environmental impacts of timber activities. As an example, the description of a management situation for air in one Guide states:

Smoke and other unpleasant but often harmless odors from garbage dumps, manure piles, sawdust burners, pulpmills, and prescribed burning projects may be annoying air pollutants in some places. Smoke may create real safety hazards near highways and airports. It is often possible to locate these smoke- or odor-producing sources where they will not hamper other uses and activities. Some polluting activities may be curtailed durnig certain periods in order to eliminate or minimize adverse effects. ${ }^{97}$

The management statements and planning assumptions referred to above are normally very general, based as they are on experience and relatively generalized inventories, surveys and analyses. ${ }^{98}$ Nevertheless, they indicate Forest Service concern with resource interrelationships, including environmental impacts pertiment to timber activities. This concern is expressed in more detail in fashioning criteria for mapping management zones and in statimg management directions and coordinating requirements for the zones.

\section{Management Zones and Coordinating Requirements}

In some zones, for example the "crest" zone at high elevations, hittle if any commercial timber will be found. The statement of criteria for, and the mapping of, "crest zones," therefore, has hittle to do with controlling environmental impacts of timber activities except to identify areas where such potential harms are unlikely.

There are two Service-wide zones, however, where commercially valuable timber often will be found, but harvesting is severely restricted im order to protect scenic, recreational, and environmental values. These are the travel and water influence zones-areas where particularly heavy public travel and recreational use are expected. ${ }^{99}$ Zoning, in these cases, embodies a decision to prefer recreational use over timber harvesting in select locations. It thus anticipates a "harmful" effect and provides directives for its control. The directives are in the form of management directions and coordinating requirements. Manageinent directions for such zones often highlight the protection of en-

U.S. Dep't of Agriculture, Forest Service Handbook, Multiple Use Management Guide, Intermountain Region ch. 114, Dec. 1965 (FSH 2121.4).

97. 1d. ch. 111.

98. ENVIRONMENTAL MANAGEMENT STUDY, supra note 74, at III-15, III-80.

99. F.S. MANUAL, supra note 75, \ 2100 (1963). 
vironmental factors, ${ }^{100}$ as do coordinating instructions relating to all activities including timber. ${ }^{101}$

Timber activities, however, are permitted and encouraged in many zones covering inuch if not most of the national forests. ${ }^{102}$ The management direction for such a zone in one region states:

Management direction for the General Forest Zone is: to grow and harvest the maximum quantity and quality of timber and forest products on a sustained yield basis consistent with other resource needs; to maintaim or improve water quality and quantity; to maintain or improve range forage production for wildlife and livestock on meadows, key winter deer range and other suitable grazing areas; to recognize dispersed and minimal recreation use and provide for site and immediate buffer needs in timber harvesting prescriptions. ${ }^{103}$

The coordimating requirements for timber activities in the zone, con-

100. The following management direction for the Water Influence Zone is contained in the Regional Guide for the Northern California Subregion:

To safeguard the public interest by maintaining or improving the on-site usefulness of water in streams or lakes, and insuring that an optimum flow or level of good quality water be maintained for recreational and other purposes; to direct recreation use toward the most suitable areas for recreation purposes; to maintain or improve habitat for wildlife with special emphasis on fish; to maintain, restore, or improve appearance of streams, channels, and shorelines; to mamtain attractive conditions in the landscape closely visible to the traveler and using public.

U.S. Dep't of Agriculture, Forest Service Handbook, Multiple Use Management Guide, Northern California Subregion cli. 48, Sept. 1965 (FSH 2121.4).

101. Pertinent coordinating instructions for timber in the Regional Guide are as follows:

2. In harvesting timber on unimproved areas within the zone where recreation use is or will become significant, design access roads, cutting and logging methods so as to retain a near natural appearance. . . .

3. Dispose of slash on all areas iminediately adjacent to recreation improvements and adjacent to highways and other heavily traveled roads.

4. In harvesting timber along stream channels where recreation use is of little importance, maintain a timber stand to result in a degree of attractiveness commensurate with anount of recreation use. Protect the stream channel by a fringe of vegetation or other ground cover of sufficient width and density to minimize the direct and adverse effects of logging and road construction on water quality and regimen.

Remove froin streain channel any logging debris which could result in significant channel blocking or side cutting or which would otherwise adversely affect water quality or regimen.

Where streams have a significant fishery or wildlife habitat value, or where downstreain fishery values require upstream temperature protection, leave a fringe of vegetation of sufficient width and density to minimize the effect of logging and road construction on the stream and riparian vegetation.

1d. ch. 29. There are other characteristic zones where timber activities are restricted in favor of some other values that would otherwise be harned. These include special zones like wilderness areas, certain natural areas, archeological sites, and the like. See F.S. MANUAL, supra note 75, $\mathbb{} 2150$ (1970).

102. Such zones go by different names in different regions. These include "general forest zone" and "intermediate zone."

103. U.S. Dep't of Agriculture, Forest Service Handbook, Multiple Use Manageemnt Guide, Northern California Subregion ch. 39, Sept. 1965 (FSH 2121.4). 
tained in the same Guide, are similar in content. They elaborate only marginally on the management direction. ${ }^{104}$ Often coordinating requirements contained in Guides, which are applicable in all zones, also provide directions for minimizing environmental harins that might flow from timber practices. They too, however, are normally quite general and non-operational. ${ }^{105}$

The drawing of zone boundaries, as indicated, is accomplished in the District Plan. ${ }^{106}$ These plans frequently delineate sinaller management units "for areas of land where special conditions require management decisions not common to the entire zone."107 In other words, the district ranger creates a special spot zone in order to facilitate specialized treatment. It is often the case that management units simply demark an area subject to a special management plan, for instance a range allotment. ${ }^{108}$ Other times the management unit is designed to protect view or to protect against soil erosion or the like, and this can entail special limitations on timber activities. Thus, the availability of the device can be useful in identifying and specially regulating an area which is particularly vulnerable. ${ }^{109}$ In addition to the zoning, the

104. Instruction 2, for instance, provides: "Design timber access roads, harvest and cultural practices to protect watershed values." Id. While this inight sensitize a inanager to consider watershed values, it hardly tells him how to do this, to what degree, and under what circumstances.

105. The following are representative samples from the Regional Guide for the Northern California Subregion:

1. Continue efforts to inprove methods of growing and harvesting timber so that results are coinpatible with protection and use of other resources. In those areas where current harvesting methods are incoinpatible with other resource values, forego timber harvest until acceptable logging inethods are developed. Where economically and technically possible, achieve inaximun sustained cominodity use consistent with protection of other resource values.

4. Require erosion prevention ineasures on timber sales and in reforestation work to ininimize soil disturbance. ....

6. Adjust logging, planting and stand improvement plans to meet the needs of big gaine on key winter range.

7. Leave sufficient hardwoods, cover openings, food areas, and den trees to ineet the needs of wildlife.

. . .

9. Provide for replaceinent of range improvenients damaged or destroyed as a result of logging operations. Natural barriers rendered ineffective by logging are to be replaced with fencing (and cattleguards where needed) where livetock drift would otherwise becoine significant.

Id. chs. 29-30.

106. See text accompanying notes 81-83 supra.

107. 1 Land Use Planning Study, supra note 8, at III-5.

108. ENVIRONMENTAL MANAGEMENT STUDY, supra note 74 , at III-34.

109. An illustration from a District Plan incorporated in the Regional Guide for the Pacific Northwest is in point:

Management Unit No. 4. Rock Creek Slide Area

Management Situations. This management unit consists of two separate, active

slide (or slump) areas which are situated on both sides of Rock Creek. The 
District Plan states management decisions that have environmental implications for the zones. ${ }^{110}$ However, these are generally amplifications of the management directions contained in the Guides and are no more specific.

The principal function of the Plans and Guides is to provide the basis for development and administration of resource management plans, ${ }^{111}$ action plans, and action programs. The Regional Guide and the District Plan, in a general way, set the stage for the Timber Management Plan which identifies with somewhat greater precision where timber activities will occur over the next ten years. The Timber Management Plan calculates and allocates the "allowable cut," and is also concerned with regeneration and timber access roads. ${ }^{112}$ The Management Plan also has lengthy sections devoted to coordination measures, many of which are concerned with avoidmg or minimizing negative environmental impacts that can flow from timber activities. ${ }^{113}$ These too are normally general and not site specific. ${ }^{114}$

\section{B. Action Planning and Multiple Use Impact Surveys}

The Regional Guide, the District Plan, and the Timber Manage-

slides are directly across the drainage from each other; the critical point, or toe, of both slides extends into the creek channel and restricts the drainage for approximately 1,000 feet. The larger slide area, on south aspect, extends up the slope for roughly 3,000 feet. The smaller area, on north aspect, is about 2,000 feet long.

These two critical areas restrict access into approximately 4,000 acres of undeveloped but productive commercial forest land. The slide areas themselves contain a moderate stand of old growth timber. Road development has currently progressed upstream to within two miles of the slides.

Management Decisions

1. The preservation of soil and water valnes will be empliasized on this management unit.

2. Road construction will not be permitted on or immediately adjacent to the slide areas.

3. Neither timber harvest nor other intensive use will be permitted in the managenent umit until a detailed study, conducted by soils specialists, provides the administration with an evaluation of proposed management practices.

U.S. Dep't of Agriculture, Forest Service Handbook, Multiple Use Management Guide, Pacific Northwest Region (FSH 2121.4).

110. 1 Land Use Planning Study, supra note 8, at III-53 to -55 . For exainple, one management direction stated in a District Plan for a travel influence zone is: "Planting will be done to enhance the aesthetics, provide a buffer effect, and improve recreational opportunities." Id. at III-53.

111. Such as the Timber Management Plans.

112. The Timber Management Plan for the Willamette National Forest, Northwest Region, containing some 17 pages of coordinating requirenients relating to these mattcrs is analyzed in 1 Land Use Planning Study, supra note 8, at III-85 to -87.

113. Id. at III-85.

114. See Environmental Management Study, supra note 74 , at III-22 to -25 . 
ment Plan try to foresee potential environmental harms and to provide general guidance to those in the field who plan and carry out particular projects. Often, however, the information and directives contained in these docnments provide insufficient bases to avoid such impacts. The California regional office in 1967 and 1968 carried out a special study directed at these problems. ${ }^{115}$ The study was undertaken after a substantial road washout on the Mendocino National Forest due in large measure to unstable soils. As is commonly done, the road was built for timber access by timber purchasers. The special team used the washout as a departure point for the study. Planning documents from other forests and districts were examined including Timber Management Plans and District Plans. The study teain found that there was insufficient information gathered on soils and geology over the route and that inanagement directions contained in the relevant planning documents were not specific enough to provide meaningful guidance to avoid the extensive impacts that occurred. The report concluded in part that extensive multiple use impact surveys should be carried out during the action planning stage, subsequent to the preparation of a Timber Management Plan. In the study committee's view:

the Timber Management Plan is broad in nature and does not adequately reflect restrictions on the use of the land. This is also true of the Multiple Use Plan.

While the District Multiple Use Plan delineates the near-view area, designates soil stability problem areas and discusses other sensitive features, it is not an action plan. As a general rule it fails to come to grips with individual program problems and needed coordination. Neither is the Timber Management Plan an action plan. It is more a measure of the potential timber production from the working circle considering any limitations needed to protect resources or other uses. There is a real need for more intensive planning, particularly in areas where competition for the various uses is high, where critical soil conditions exist, in municipal watersheds, etc. ${ }^{116}$

The Regional Forester approved the report's recommendations that written impact surveys be required on all in-Service as well as outService projects. ${ }^{117}$

The report also addressed soil stability problems-problems particularly relevant to timber management and related access road development:

Various degrees of unstable soils exist on every National Forest in

115. Forest Service, U.S. Dep't of Agriculture, California Region, Report of Comm. on Multiple Use Problem Analysis, Jan. 19, 1968 (Recer Ridge Road, Mendocino N.F.).

116. Id. at 3. One of the Committee's recommendations was for further training of Forest Service officials in multiple use planning. Id. at 1.

117. Id. at 2. 
the State. Consideration is given to soil problems on most projects undertaken whether 'In-Service' or 'Out-Service.' Erosion hazard imdices have been developed and are in use. Even these do not assure complete success on all soils. Professional expertise of soil scientists, engineer-geologists, and engineers is also needed in planning and activating projects. Knowledge of local soil conditions from past experience is also helpful. Even with best expertise there is no guarantee or cure-all for soil stability problems. When used they do help. There are too few professional engineer-geologists and soil scientists to do an adequate job of studying and making recommendations for the many projects undertaken by the Service and its permittees.

With the exception of the Cleveland and the Mendocino Forests' almost complete soil surveys, there are no other National Forests in ... [Region 5] on which a standard soil-vegetation survey has been coinpleted. Thus a basic resource appears to be getting insufficient attention. ${ }^{118}$

The report contained a number of recommendations concerning the provision of trained personnel and the application of an erosion hazard rating system that were approved by the Regional Forester to the extent of available funding. ${ }^{110}$

118. Id. at $4-5$.

119. Detailed Committee recommendations, and the regional forester's action proposals, are exemplified by the following:

4A. Assign an engineer-geologist to each timber producing forest having unstable soils and on those other forests where heavy road construction is planned in unstable soils.

Action. Engineer-geologists are and will continue to be recruited and assigned as funds and ceilings become available. To date we have engincer-geologists on four National Forests in the Region.

4B. Assign soil scientists to all forests or combination of forests as needed to assist in proposed project planning in areas of unstable soils and to start reconnaissance surveys to assist in soil vegetation mapping.

Action. Additional soil scientists are being recruited and assigned as funds and ceilings become available. We now have soil scientists on five National Forests. The Division of Watershed Management will be in touch with you to get sound programs of assistance to project planning and soil recounaissance surveys under way.

4C. Develop and initiate a program of training engineer-geologists in soil science and soil scientists in engineering geology so they can better perform the overall job needed in working with unstable soils.

Action. The Divisions of Engineering, Personnel, and Watershed Management will collaborate on this and have a training program functioning in Fiscal Year 1969.

4D. Develop and initiate a training program to better inform foresters, engineers, and other professionals in how to recognize areas of unstable soils and what to do once recognized.

Action. The Division of Watershed Management, working with the Division of Personnel, will initiate this program in F.Y. 1969.

4E. As funds become available increase the progress in soil vegetation mapping.

Action. This will be undertaken as soon as funds do become available. However, in the interim Forests should take full advantage of the time available to get their soil scientists engaged in this program starting with the primary problem areas. 
Evidenced here are the concern and the California Region's activities designed to anticipate, in the planning stages, various environmental harms produced in timber operations, especially ones related to soil stability and erosion. Forest officials determined that this could best be done at the action planning stage.

Action planning is the stage when timber sales are being sketched out to fulfill the allowable cut allocations of the Timber Management Plan. Each planned sale is to be made the subject of an impact survey. ${ }^{120}$ If special problems are anticipated, an interdisciplinary teain hopefully can be organized to assess unique dangers. Between action planning and the actual preparation of timber sales, progress may be stopped if especially harmful risks are uncovered. If they are not, the design of the timber sale should reflect the information developed in the survey. The value of the survey, of course, largely depends on the expertise brought to bear and the depth and quality of information actually gathered.

\section{Action Programs: Timber Sales}

The activity described above results in timber sales. In some circumstances, the plans and impact surveys have developed considerable information that isolates areas that should not be timbered because the risks of deleterious environmental impacts are too high. This may lead to a policy determination to prefer other resources such as recreation or scenic values to timber harvest. The inforniation developed by these surveys also guides the ranger in designing the particular sale so as to minimize adverse impacts and to maximize positive ones. ${ }^{121}$ The design of the sale, however, is also heavily influenced by the timber management directions contained in Forest Service Manual and the Regional Supplements. ${ }^{122}$ Special nieasures to be undertaken to protect against environmental harms required by these directions are made part of the timber sale contract that is signed by both the purchaser and a Service official.

\section{Special Management Directions}

Exainples froin the Forest Service Manual, Regional Supplements, and contract provisions illustrate special management directions to protect environmental values in designing timber sales. The standard form

Memorandum from J.W. Deinema to Division Chiefs and Forest Supervisors, Region Five, California 3-4, Apr. 12, 1968.

120. F.S. MANUAL, supra note 75, \2141.3 (1963).

121. One example of an adverse impact is soil erosion. A positive impact could be achieved by cutting in such a way as to provide accessible forage for deer.

122. See note 75 supra. 
Forest Service timber sale contract contains provisions regarding stream flow protection, erosion protection, recreational and scenic values, and reforestation. One contractual limitation, for instance, provides that "the purchaser's operation shall be conducted reasonably to minimize damage to stream courses." ${ }^{.123}$ The contract then elaborates the measures that must be undertaken to acconiplish this. ${ }^{124}$ The Region 4 Supplement contains a host of provisions applicable to timber harvesting that relate to miany environmental subjects. ${ }^{125}$ These include model contract provisions covering important topics such as one intended to provide for revegetation of exposed roads, skid trails, and the like. ${ }^{128}$ Other contract provisions treat tractor skidding and erosion prevention by limiting motorized travel through natural meadows to specified crossings. ${ }^{127}$ The success of such provisions, of course, rests

123. Forest Service, Dep't of Agriculture, Timber Sale Contract, Forest Service Form 2400-5, Apr. 1966 [hereinafter cited as Timber Sales Contract].

124. Id. pt. B6.5. Moreover, the contract provides that:

Within Sale Area and along roads constructed hereunder streamcourses shall be cleared of debris directly resulting from Purchaser's operation and which may affect the natural flow of the stream.

$\cdots$

Unless otherwise agreed to, the following measures shall be observed:

Culverts or bridges will be required on temporary roads at all points where it is necessary to cross such designated streamcourses. Such facilities shall be of sufficient size and design to provide unobstructed flow of the water. Logs shall not be otherwise hauled or yarded across streamcourses, unless fully suspended or the streamcourse is frozen.

Heavy equipment will not be operated in such designated streamcourses except at designated crossings and as essential to construction or removal of culverts and bridges.

When a stream is temporarily diverted as a result of Purchaser's operations, it shall be restored to the natural course as soon as practicable and in any event prior to a major runoff season.

Id. In addition, as stated in George Banzhaf \& Co., Public Land Timber Policy 2-35, 2-36, 1969 (prepared for the Public Land Law Review Comm'n):

Division $C$ of a contract may provide that so-called sensitive stream courses are to receive the protection specified in B6.5 at all times, and that resistant stream courses receive the protection specified in B6.5 during periods of seasonal runoff but at other times logs may be yarded or hauled directly across the stream courses. The purchaser is often required to remove operational debris from resistant stream courses and repair purchaser-caused damage to the bed and banks where the natural flow of water might be obstructed by such damage. It should be noted that these Division $\mathbf{C}$ provisions are examples, and are not used in every contract or in every region.

125. Dep't of Agriculture, Forest Service Manual 2458.9, Region 4 Supplement, Jan. 18, 1967.

126. Id. No. 107, provision 6.623:

Erosion Control Seeding on Areas Where Logging is Completed. The Purchaser shall furnish and sow suitable grass seed where staked or otherwise marked on skid trails, firelines, roadways, road embankments, fill sections, and landings. All seed used must be approved in advance by the Forest Service. Grass sown shall be evenly spread at the rate of - pounds per acre in the early spring when moisture conditions are favorable, or in the late fall.

127. ENVIRONMENTAL MANagement Study, supra note 74, at III-27. In addition, the Region 4 Supplement contains lengthy and highly detailed provisions on erosion pre- 
heavily on their actual use, the training and experience of workers on the ground, and the extent of Service supervision.

Another Regional Supplement contains special cutting provisions for watershed management. ${ }^{128}$ It provides, as an example, that in areas where the quantity of water yield and the timing of runoff are important, a major objective in managing the timber harvest will be to increase or decrease water yield as desired. ${ }^{128}$ Increasing the density of the timber stand will reduce water yield, and decreasing that density will increase water yield. Various methods of cutting are recommended in order to correlate timber harvesting with desirable watershed management practices. ${ }^{130}$

A draft Supplement issued in California contams instructions on timber cutting in areas of high aesthetic interest. ${ }^{131}$ It includes text and pictures covering a variety of subjects among which are vista openings, providing variety along roadsides, treatunent of transition vegetation, internediate cutting in open woods, clearing of slash and debris, leaving attractive trees, restoration, and guidelines regarding how a forest should look. While one might argue on the merits with particular decisions, the Supplement illustrates that the Forest Service is aware of aesthetic problems related to timber harvesting in areas used by the public, and that it is attempting to do something to minimize what its decision makers conceive to be the scenic harms.

\section{Supervision}

Where environmental protection measures are written into the timber sale contract, their performance is the responsibility of the timber purchaser. The Forest Service seeks to assure this performance through on-site supervision by Forest Service personnel. Penalties can be innposed on the purchaser if his performance is deficient. The Forest Service timber sale contract ${ }^{132}$ contains two provisions of special relevance. One calls for inspection and acceptance of work by Forest Service officials upon purchaser request. ${ }^{138}$ The other requires the

vention and control on timber sale areas that establish guidelines for appraising erosion potential, describe measures for prevention and control, and enumerate natural pliysical factors to be considered in pre-logging planning, logging operations, and postsale operations. Road construction and equipment used in logging are specified in detail. Dep't of Agriculture, Forest Service Manual 2482, Region 4 Supplement No. 211, Oct. 1961.

128. ENVIRoNmental MaNagement Study, supra note 74, at III-26.

129. Id.

130. Id.

131. Dep't of Agriculture, Forest Service Manual 2405.12-1, Region 5 Supplement, Oct. 1969 (prelim. draft).

132. Timber Sale Contract, supra note 123.

133. Id. pt. B6.33: 
maintenance of a surety bond. ${ }^{134}$ Thus through detailed contract provisions, inspection, acceptance, and performance bonds, the mechanics exist for close supervision.

\author{
V \\ ENVIRONMENTAL MANAGEMENT OF THE PUBLIC LANDS: \\ AN EVALUATION BASED ON FOREST SERVICE TIMBER \\ PLANNING AND MANAGEMENT
}

Having set forth a series of criteria earlier in this Article against which the adequacy of the systems of environmental management used by public land agencies may be judged, ${ }^{135}$ the stage is set for an evaluation of Forest Service practices. This evaluation slould, by way of analogy, also cast light on the practices of other land management agencies. Comparison of current practice and the ideal criteria will proceed under the following headings: Authority and Responsibility;

Acceptance of Work. Upon written request by Purchaser for inspection and acceptance of work and with assurance that such work has been coinpleted, Forest Service shall perform such inspection and shall endeavor within five days thereof to furnish Purchaser with written notice either of acceptance, or of additional work remaining to be done so as not unnecessarily to delay progress of Purchaser's activities. In the event that Forest Service is unable to inake such inspection within 10 days, Purchaser shall be notified of necessity for postponement and time when inspection can be made. Such request inay be for acceptance of specific requirements (such as logging, slash disposal, erosion control, or snag and live cull tree felling) or all contract requirements of a subdivision of the Sale Area. When all contractual work of purchaser has been accepted for any subdivision of the sale, said subdivision shall be eliminated from Sale Area on request of either party to this contract.

134. Id. pt. B9.1:

Performance Bond. As a further guarantee of the faithful performance of the provisions of this contract, Purchaser delivers herewith and agrees to maintain a surety bond in the dollar amount stated in A22. Any adjustment or extension of time for completion of this contract beyond one year inay be granted only with the consent of surety on said bond or delivery of a new bond. Should the sureties on the bond dehivered herewith, or any bond delivered hereafter, in connection with this contract, become unsatisfactory to Forest Service, Purchaser will, within thirty (30) days of receipt of demand, furnish a new bond with surety solvent and satisfactory to Forest Service. In lieu of surety bond, Purchaser may deposit into a Federal depository, as directed by Forest Service under B4.21, and maintain therein, cash in the dollar amount stated in A22 or negotiable securities of the United States having market value at time of deposit of not less than the dollar amount stated in A22.

As soon as security for the performance of this contract, or the settlennent of claims incident thereto, is no longer necessary, deposits which may have been made in lieu of surety bond shall, subject to the conditions set forth in B9.3 be returned to Purchaser, or appropriate notice shall be given to performance bond surety.

135. See text accoinpanying notes 115-20 supra. Much of what follows was developed originally by the authors in U.S. DEP'T OF COMMERCE, PUBLIC LAND POLICY AND the Environment, Part IV, Policy Issues and Alternatives (1970) (prepared for the Public Land Law Review Commission by I.M. Heynan, R. Twiss \& R. Hansen). 
Criteria and Standards; Information and Analysis; Planning and Management Practices; Supervision and Enforcement; and Public Participation. ${ }^{136}$

\section{A. Authority}

The Multiple Use and Sustained Yield Act of $1960^{137}$ principally, and other statutes peripherally, ${ }^{138}$ provide the Forest Service with adequate legal authority to protect environmental values in the course of accomplishing its companion statutory mandate to provide for a sustained yield of timber for harvesting. However, while some recently adopted statutes, especially the National Environmental Pohicy Act of $1969,{ }^{139}$ the Water Quality Improvement Act of $1970,{ }^{140}$ and the Air Quality Act of $1967,{ }^{141}$ and some newly promulgated Executive Orders, ${ }^{142}$ are of relevance, there is no statute or exeeutive Order that specifically directs the Forest Service to maintaim particularized standards of environmental quality in carrying out its activities including timber sale. Thus, the Service is enabled but not directed, and its choice of priorities and standards is largely its own.

\section{B. Criteria and Standards}

The various policy statements concerning environmental protection embodied in directives issued by the chief of the Forest Service and set forth in the Forest Service Manual, Regional Supplements, Regional Guides, and District Plans are either very general "motherhood statements,"143 or very specific management prescriptions based on particular experiences. ${ }^{144}$ The former provisions express concern and sen-

136. These headings are based on the analytic categories stated in the text at pt. $\Pi$, $B$ supra. See note 66 supra.

137. 16 U.S.C. $\$ \$ 528-31$ (1964).

138. See, e.g., id. $\$ \$ 475$ (purposes for which national forests are established, and administered), 476 (sale of timber), $482 \mathrm{~h}-1$ \& $482 \mathrm{n}$ (protection of scenic valucs in certain mining operations), 497 (uses and occupancies under permit), 522-23 (rights of way for various purposes), 528-31 (multiple use and sustained yield), 551 (protection of national forests), $552 \&$ 552a (watershed protection).

139. 42 U.S.C. $\$ \$ 4321-47$ (Supp. V, 1970).

140. Public I. No. 91-224, 84 Stat. 91. Section 103: "Cooperation by All Federal Agencies in the Control of Pollution," amending Federal Water Pollution Control Act, 33 U.S.C. $\$ \S 466-466$ n (Supp. V, 1970).

141. 42 U.S.C. §§ 1857f1-f7 (Supp. V, 1970).

142. Exec. Order No. 11,507, 35 Fed. Reg. 2573 (1970) (Prevention, Control and Abatement of Air and Water Pollution at Federal Facilities); Exec. Order No. 11,514, 35 Fed. Reg. 4247 (Protection and Enhancement of Environmental Quality).

143. For example, "encourage prevention or abatement of pollution from forestry-related enterprise." ENVIRONMENTAL MANAGEMENT STUDY, supra note 74, at III-2.

144. For example "the Purchaser shall furnish and sow suitable grass seed ... on skid trails . . . ."Id. at III-26. See examples in note 101 supra. 
sitize managers and supervisors to environmental considerations; the latter statements lay down absolute rules of conduct to prevent the reoccurrence of already experienced detriments. But there is a lack of clear criteria and potentially achievable operational standards for measurable elements of environmental quality, even though water and air pollution standards now emerging might serve as examples for expanding measurable objectives for other components of the environment. Without a broad spectrum of standards for different aspects of the total environment-open space, visual parameters, parks, and wildlife-environmental quality considerations cannot hold a strong position in the decision-making processes which govern timber practices and other forestry activities.

This problem might be addressed by developing an environmental quality land classification system incorporating a range of standards, one for each aspect of the environment. ${ }^{145}$ This zoning process would be designed to establish various degrees of ecological integrity, each zone with a separate permissible level of disturbance in terms of various characteristics, such as vegetative change, soil compaction, and air and water quality. The Forest Service zoning system ${ }^{146}$ could be adapted to this purpose, though with some difficulty. In a rudimentary form, it already reflects such considerations. For example, in describing management situations in a crest zone a Regional Guide might well indicate that soil erosion associated with timber harvesting is a problem that must be considered. But the present zoning system does not establish with specificity the measurable degree to which existing environmental characteristics must be retained. There are no operational standards set forth and therefore no clear guidelines for directing and assessing the performance of field personnel.

Making the suggested classification system workable and effective would not be an easy undertaking. It is especially difficult to map environmental zones because to do so requires vast amounts of data and inventory material and involves the transitional nature of different environments. However, even if no highly prescriptive zoning map emerged, the classification effort would force agencies such as the Forest Service to begin developing specific criteria for environmental quality which would provide field level personnel with clear guidelines.

\section{Information and Analysis}

Sound environmental standards cannot be established in the absence of rehable and available information. Although single-purpose

145. Such a system is in fact urged by the Public Land Law Review Commission. Public Land LaW Review Comm'n, One Third of the Nation's Land 73-80 (1970).

146. See text accompanying note 81 supra. 
exploitation or preservation requires only minimal amounts of information, the alternative, environmental management, is strongly dependent on large quantities of relevant and accurate data. The justification for environmental management rests heavily on the assumption that through study and scientific judgment, the ecosystem can be manipulated with foresight and control. Thus, information, and the mechanisms for insuring its availability, relevance, and vahdity, are of primary concern. Generally speaking, however, information now used by the Forest Service in environmental management varies from being adequate to being marginally useful, depending on the scale of decision and the time, persoimel, and funds allocated to study.

\section{Regional Level}

There is a lack of information on environmental characteristics at the regional level of the Forest Service. Broad land-use policies and coordinating requirenents are promulgated in Regional Guides and Supplements on the basis of assumptions and available information which-although it may indeed be the best available-is overly general, only marginally relevant, and commonly incomplete. An excellent example of this is found in the special study carried out in the Cahfornia Region after a substantial road washout on the Mendocino National Forest due largely to unstable soils. ${ }^{147}$ That study estabhished that with regard to soil stability characteristics of national forest lands within the region, there was no valid, available information at the regional, forest, or district level upon which to premise operational directives. Similarly, there were no comprehensive and available data on geologic instabilities, water quality, and other like featurcs, and this is still the case.

This problem could be ameliorated by compiling environmental infornation for all the public lands within a region, and making the maps and documents available through designated regional hibraries or centers. This would provide a focal point for information access and for agency coordination, and would permit the pooling of the research resources of different management agencies. Existing research centers, such as Forest Service experiment stations, could be utilized at the outset of such a program.

\section{Planning Unit Level}

Information at the forest and district levels is incomplete and widely scattered through reports and memoranda. ${ }^{148}$ Yet many de-

147. See text accompanying notes 115-20 supra.

148. These imclude functional inanagement plans, District Plans, inpact surveys, special reports, and inspection reports. 
velopment alternatives and policy conflicts are resolved at these levels, especially those addressed in the functional plans and the District Plan. Because pertinent information is unavailable, however, environmental concerns tend to be put off or overlooked in the fast pace of day-to-day work and decision making.

\section{Site Level}

Impact surveys are characteristically used by the Forest Service to evaluate the effects of major projects ${ }^{149}$ on the project site and its surroundings. But these studies are often inadequate in that they may be done quickly, with hittle or no original data, or may be completed well after irreversible development decisions have been inade. Many are based on superficial and overly general background data, and fail to consider project rejection, as well as impact mitigation measures, as an alternative. ${ }^{150}$ Moreover, the surveys are not even conducted for some major projects.

The impact survey device is capable of uncovering subtle ecological relationships, avoiding harmful environmental consequences, and applying general environmental precepts to specific developmental undertakings. To be useful, however, impact surveys must be done routinely and well. It would be advantageous if agencies such as the Forest Service promulgated uniform policies and procedures for impact surveys. For example, policies should require that impact surveys be conducted for all timber sales involving over 100,000 dollars or over 40 acres of land, that a minimum of one year be provided for study, and that surveys include an assessment of environmental ramifications and of costs and benefits, both with and without the project. ${ }^{151}$

\section{Personnel and Funding}

The Forest Service unlike other agencies such as the Bureau of Land Management, has a number of scientists and other professionals as employees. In the California Region, for instance, there are 741 tramed foresters and 143 civil engineers administering over 19 million

149. For instance, timber access roads and timber sales.

150. See, e.g., ENVIRONMENTAL MANAGEMENT Study, supra note 74 , at III-75 to -78 (analysis of the Forest Service Dos Rios River Impact Survey Report, Phase II).

151. The detailed statement required by section 102(c) of the National Environmental Policy Act of 1969, 42 U.S.C. $\$$ 4332(c) (Supp. V, 1970), to be included "in every recommendation or report on proposals for legislation or other major Federal actions significantly affecting the quality of the liuman environment" should be a stimulant for the routine undertaking of such impact surveys. For an interesting exploration of the type of studies desired by conservationists in a contemporary battle see Reed, Oil and the Artic Tundra, Nat. Parks \& Conservation, Nov. 1970 at 4. 
acres of national forest land. ${ }^{152}$ In addition, the Region employs some 64 scientists and 34 other professionals. ${ }^{153}$

Despite the relatively advantageous position of the Forest Service, there are still insufficient personnel for the collection, translation, and infusion of environmental information into the Service's decision-making system. There are at least three ways to remedy this insufficiency. First, existing agency research and management staff personnel, and financial resources, could be expanded. Secondly, an independent, government or quasi-government, ${ }^{154}$ research and development organization could be created or designated which would accomplisli any or all of the followig functions: compile background information for national or regional planning purposes, set standards for research and impact studies, conduct or sponsor environmental surveys, advise on or conduct impact surveys, consult on environmental impact problems, supervise field tests of new technology or land development practices, provide independent review or assessments of agency studies, and perform project inonitoring. Finally, an inter-agency program for environmental manageinent studies could be created. Certain research, survey, and staff functions in the Forest Service, Park Service, and the Bureau of Land Management and possibly the Bureau of Sport Fisheries and Wildlife, United States Geologic Survey, and the Soil Conservation Service, could be linked through nenuoranda of understanding. ${ }^{165}$ A joint committee could advise on direction and content of surveys and study projects. ${ }^{156}$

152. ENVIRoNMENTAL MANAGEMENT STUdY, supra note 74, at III-79.

153. Id. The California State Office of the Bureau of Land Management which administers some 15 million acres, on the other hand, has only 24 foresters, 24 range conservationists, 35 resource managers, three wildlife speciahists, thrce landscape architects, and one geologist. Id. at IV-69.

154. A number of approaches are being discussed in agency circles such as: a RAND type of private firm directly tied to government contracts but with some inde-pendence of direction; an amalgam of federal laboratories and inventory groups now hemmed in diverse agencies; an environinental survey and research laboratory under the Executive Office (or the Smithsonian Institute, for example); and a number of other possibilities including linkages with umiversities.

155. Cooperative arrangements are often established by Memoranda of Understanding, Memoranda of Agreement, and Cooperative Agreements. These apparently differ in name only. They are contracts between departments, agencies, or sub-units of agencies or various combinations of these. Often nonFederal bodies, such as state agencies or local groups, are parties as well. The subject matter of such agreements generally depends on the governmntal levels involved. Agreenents between departments (e.g., Agriculture and Interior) and/or agencies (e.g., the Forest Service and the Bureau of Land Management) usually reflect agreements respecting common policy goals or general divisions of responsibility. Agreements between smaller units (e.g., a Regional or National Forest Service Office with the Soil Conservation Service or the Wildlife Service) often concern a specific project.

1 Land Use Planning Study, supra note 8, at III-21 to -22 .

156. Often, different federal agencies establish joint bodies for various purposes. 


\section{Planning and Management Practices}

Research and survey information regarding environmental quality inust be brought to bear on decision-making in order to be effective. One way to accounplish this is through directives stating what is to be taken into account in inaking particular decisions and what weights are to be given to various considerations. Another is through the planning process where, in general, different activities are assigned different spatial areas.

\section{Agency Directives}

Forest Service directives, as well as those of other agencies, concerning environmental quality are often very broad and simply sensitize administrators to environmental considerations without giving them directions as to what factors should be taken into account and what weight is to be given to thenn. This, of course, is due in inajor part to the lack of systematized information. The recent environmental objectives statements by the chief of the Forest Service, ${ }^{157}$ for instance, are very vague, although some amplifying statements of Regional Foresters are more precise. ${ }^{158}$

The Council on Environmental Quality should give serious consideration to requesting that all federal land management agencies formulate a set of directives that are as detailed as possible concerning the specifics of environmental quality. ${ }^{159}$ These should be given wide circulation, and adequate opportunity should be allowed for the comments of interested persons and groups. This undertaking would be yet another means for stimulating the gathering and analysis of information. It would generate self-conscious efforts by agency experts to foresee and deal with environmental dangers, and it would provide specific guidelines for the anticipation and amehoration of environmental harms to land managers who are not experts.

For instance, the Committee on Water Resources Policy coordinates Forest Service water resources planning with that of other land management agencies. Id. at III-22. Similariy, federal and state agencies on occasion constitute joint bodies for various matters. This device is used extensively by the Forest Service and state fish and game agencies regarding wildlife. Id. at III-127 to -138 .

157. See note 74 supra.

158. See note 74 supra.

159. Authority for this is contained in section 102(2)(B) of the National Environmental Policy Act of 1969, 42 U.S.C. $\S 4332(B)$ (Supp. V, 1970) that requires all agencies of the federal government to:

[I]dentify and develop methods and procedures, in consultation with the Council on Environmental Quality . . . which will imsure that presently unquantified environmental amenities and values may be given appropriate consideration in decision-making along with economic and technical considerations .... 


\section{Zoning}

Large regions within which the Forest Service and other federal land management agencies operate contain definable areas which exhibit particular environmental sensitivites. These include proneness to earthquake hazard, soil slippage, erosion, air pollution, fragihty of a wildlife resource such as anadromous fish, and the like. Identification of these areas is a problem, ${ }^{160}$ but if relevant identifications are made, a systematic means must be established for utilizing such information.

This could be done by mapping relevant areas at the regional level and stating particular management directions to guide the forest and district personnel in determining uses within the areas and necessary ameliorative steps. Such zoning is an efficient way to transmit the information in an authoritative manner. It is especially applicable in the Forest Service planning system which already provides zoning information in the Regional Guides. Moreover, the system would provide a good basis for determining when specialist teams should be dispatched to design a particular project, sucli as a timber access road.

\section{Prerequisites For Action Plans and Programs}

Directives and planning activities that seek to uncover resource and use relationships prior to the design of a particular project such as a tinber sale are usually too general to identify particular environmental dangers. For instance, in the situation of stream pollution from a road, the coordinating requirements and management directions in the Regional Guides and District Plans rarely pin-point specific areas of particular sensitivity or set forth precise measures needed to avoid environmental damages in the particular location. ${ }^{161}$ One way to remedy this would be to require intensive data gathering and analysis at district or sub-district levels, and the preparation of map overlays which record such information before significant projects are undertaken. The ranking of such information would help assure sensitive consideration of environmental dangers whenever a resource or activity decision was to be made, but its compilation would be very expensive and hittle of it would be used for any particular project.

A more economical means for designing particular projects sensibly is the inpact survey. ${ }^{162}$ These should be required at the action planning stage, before actual project design, but after the general alternative locations for the project have been determined, and should be carried out by experts at the regional or forest levels when they are to

160. See text accompanying notes 145 \& 148 supra.

161. The example given in note 109 supra is an exception.

162. See text accompanying notes $150-51$ supra. 
occur in areas identified as potentially sensitive. Further, the studies should be completed and reviewed prior to the letting of any bids, or the decision to fund or commence any agency project. Too often, impact surveys are still being carried out as the project is being designed or commenced.

Directives and planning documents cannot anticipate all problems or set forth with precision what values are to be given determmative weight in all instances. Land managers, such as District Rangers, and their immediate superiors, Forest Supervisors, have to take ultimate responsibility for resource and activity decisions. However, without a widely-used process which assures that the managers will give sufficient attention to environmental issues in making individual decisions, only minimal attention can be expected.

Directives could be drafted that stipulate the general environmental considerations that should be consciously weighed by the land manager with regard to each important resource or activity decision. The directives might mcorporate the directions contained in the National Enviroumental Policy Act of $1969,{ }^{163}$ - to consider for every important resource and activity decision:

the environmental impact of the proposed action, . . . any adverse environmental effects which cannot be avoided should the proposal be implemented, ... alternatives to the proposed action, . . . the relationship between local short-term uses of man's environment and the mamtenance and enhancement of long-term productivity, and .... any irreversible and irretrievable commitments of resources which would be involved in the proposed action should it be implemented. ${ }^{164}$

This type of system would focus the land manager's attention on the environmental consequences of his acts, would require him to assess alternatives, would make him sensitive to his lack of authority, if any, and would put him on notice of the standards against which his performance will be measured. It could be buttressed by the adoption of a form specifying the considerations outlined above, which must be completed and signed by the manager before a project is undertaken.

Despite the potential advantages of such a system, three potential disadvantages are evident. First, the statement calls for a sophisticated judgment based on considerable data, both of which might be lacking, especially at the manager's level. Second, the process might inhibit any action where there is any chance of environmental harms occurring especially as the manager might be lield responsible for unanticipated harms. Third, the system might eventuate in many more decisions be-

163. 42 U.S.C. ริฐ $4321-47$ (Supp. V, 1970).

164. Id. $\S 4332(\mathrm{c})$. 
ing deferred to higher levels than is presently the case.

\section{Defining the Responsibilities of Permittees}

Many management decisions, like timber sale contracts, are carried out by incorporating precise conditions and directions in contracts and permits which control the actions of private persons and corporations who make use of agency resources. Contract and permit provisos must be definite in order to be effective. Often, however, they are indefinite and do not spell out precisely the obligations of the permittee.

Region Four of the Forest Service deals with this problem in the case of timber sales by having prepared standard form contract provisos at the regional office which cover many anticipated environmental hazards. ${ }^{165}$ These can be imserted by land managers in contracts with few modifications and specially written insertions. While the effort is expensive, the advantages are numerous. Instrument drafting is difficult, and expert resource and legal talent can be assembled at higher levels. Well-drawn provisos provide a usable reference hist for managers as well as a control device. The drafting of model provisos requires agency personnel to think through environmental problems in an operative context.

The Region Four approach is considerably better than incorporating by reference in the contract the regulations and other directives of the Forest Service. Under that system, particular environmental problems are not brought to the attention of the land manager or permittee and the chances of effective enforcement are less probable im the absense of a specific and noticed agreement.

\section{E. Supervision and Enforcement}

All land management agencies including the Forest Service have internal procedures for monitoring and supervising their own land inanagers and for enforcing conditions placed on permits and licenses. ${ }^{160}$ These are crucial activities. Directives, plans and management directions regarding environmental quality might be exemplary; without adequate supervision and enforcement, however, they can become nullitites.

\section{Enforcement of Contract and Permit Conditions}

To the extent that available personnel allow, the Forest Service and other agencies supervise timber harvesting and other permit operations.

165. See notes 126-27 supra.

166. The Forest Service has an extensive system of internal inspection and control. See 1 Land Use Planning Study, supra note 8, at III-13 to -14. 
Where federal officials cannot provide on-site inspection, there is a normal tendency to disregard relevant conditions and regulations. The lack of available funding for inspectors should be helped by requiring that permittees pay fees ample to support supervisorial personnel. ${ }^{\mathbf{1 6 7}}$

If a permittee negligently or willfully undertakes harmful activities, or disobeys conditions designed to protect environmental quality, difficulty can be encountered in collecting damages to pay for the correction of the harm. Statutes, regulations, or directives should embody standards guiding the discretion of land managers and agency and United States attorneys in determining whether or not to bring civil suits to recover damages. The standards should require suits to be brought in most instances. Moreover, perforinance bonds, modelled on the Forest Service timber sale contract proviso, ${ }^{168}$ should be required as a matter of course.

Finally, the Forest Service, and other agencies, should be authorized, at least on an experimental basis, to adopt schedules of civil fines that will be imposed for specific transgressions. The fines should be realistic in amount so as to deter harmful conduct, but not so large as to be difficult to impose. The amounts, however, should bear soine reasonable relation to the cost of reinedying the harms created by the transgressions. Fines should generally be imposed by land managers subject to administrative, and limited judicial, review.

In nrany instances, adequate supervision requires constant monitoring of the environmental impacts of an activity that has been undertaken under a permit. This can be true for the maintenance of a timber access road or with respect to recreation activities carried on at hotels, retaurants, or skiing facilities. It is also true where unforeseen pollutants might be produced which affect the quality of a stream or lake. To guard against these impacts, constant or periodic monitoring processes must be used. These can range froin inspections to automatic counting devices. ${ }^{169}$ Often such processes are not used and harmful environmental conditions do not come to agency attention until they have progressed to dangerous or highly distasteful levels. Earlier discovery, moreover, would often permit cheaper amelioration.

\section{Supervision of Agency Personnel}

Inspection of the performance of land managers by supervisery

167. This is a standard practice under building codes, zoning ordinances, and subdivision regulations.

168. See notes 133-34 supra.

169. For example, recording devices to record water quality in streams, air pollution sensors, or even time-lapse photographs from "visual control points" such that changes in scenery caused by forest harvest or road construction would be made a inatter of record for time-series coinparisons. 
personnel is a well established practice in the Forest Service ${ }^{\mathbf{1 7 0}}$ and, to a lesser extent, in other agencies. ${ }^{171}$ It is the primary control system to assure the adequacy of environmental management practices. To be effective for this purpose, however, the inspectors must take environmental consequences of activities seriously, and must be thoroughly acquainted with the environmental impacts that are to be noted.

In order to build up usable experience concerning successful and unsuccessful environmental management practices, regular means for reporting and reviewing the adequacy of particular programs must be developed and utilized. This requires building an evaluation component into various management programs such as timber management, a practice often lacking in line agencies, including the Forest Service. Evaluation, in turn, requires a statement of a measurable goal before the program begins and analyses during and after the program to determine to what extent the goal has been realized. Forest Service annual work programs should require a statement of a measurable environmental goal for selected undertakings, ${ }^{172}$ establishment of "experimental conditions" so that a particular system designated to attaim the goal can be tested, and a means for reporting the results for agencywide use.

\section{F. Public Participation}

Public participation in agency decision processes is quite uneven. There are different rules and practices from agency to agency and within agencies with respect to different fnnctional and planning programs. For instance, there is little public participation in the formulation of Forest Service Regional Guides, District Plans, Timber Management Plans and, normally, only inarginal public access to impact surveys. ${ }^{173}$ Public participation through formal public hearings is generally disliked by agency managers. Hearings, however, and other devices for participation, can serve several salutary environınental purposes. The pressure of public opinion focused on a particular decision might bring new information to agency attention. Preferences are communicated and inadequate analyses are pin-pointed when the public participates in what otherwise might be clandestine decisions.

Formal public liearings should be required before decisions are made when they involve substantial environmental risks. The Forest

170. See note 166 supra.

171. See, e.g., U.S. Dept. OF the Intertor, Bureau of Land Management MANUAL ch. 1240.

172. For instance, water quality in a particular stream of $x$ quality.

173. "Moreover, [Regional] Guides and [District] Plans are seen primarily as 'internal' documents. There are few mechanisms for public, other agency, or private organization review." 1 Land Use Planning Study, supra note 8, at I-17. 
Service and other agencies should set up categories of decisions that must be preceded by public hearings at an early enough time so that the testimony presented can be used in making the decision. The categories should be enunciated in a rule-making process in which citizen groups can participate. Adequate opportunity to affect decisions will require, in many instances, double hearings similar to those now required for certain federally-aided highways, ${ }^{174}$ the preliminary release of enough information to permit meaningful discussion of the major issues, adequate notice, a detailed presentation by the managing agency of the potential costs and benefits of the proposed undertaking, and a written public report following the hearings justifying the decision with respect to arguments made at the hearings.

Other mechanisms are also needed to inform the public of environmental problems, to seek public viewpoints, and to permit public inquiry. The Forest Service and other agencies make considerable use of various advisory boards. ${ }^{175}$ These boards are either commodityspecific $^{176}$ or are organized on a territorial basis-at regional or forest levels. They include representatives of various interest groups. In addition, however, advisory boards should be constituted that are primarily concerned with environmental issues. Alternatively, existing advisory boards might be enlarged to include a substantial number of environmentalists. The agencies should involve these boards in reviewing major proposals involving risks of environmental degradation and agency practices generally regarding environmental quality.

174. 23 U.S.C. $\S 128$ (a) (Supp. V, 1970). See also U.S. Bureau of Public Roads, Policy and Procedure Memorandum 20-8, Jan. 17, 1969; Aman, Urban Highways: The Problems of Route Location and a Proposed Solution, 47 J. URBAN L. 817 (1970).

175. 1 Land Use Planning Study, supra note 8, at III-225, III-23, IV-54; 2 id. at III-105, IV-184.

176. As of June 30, 1968, the Forest Service liad 166 public advisory committees. Most of these functioned in relation to particular national forests. Their members are chosen by Regional Foresters and Forest Supervisors who are directed to base selection on the individual's familiarity with various aspects of Service concern. Fields of interest are stated to include water, timber, range, wild land ownership, recreation, wildlife, farmers, labor, business and industry, mining, and education. Appointing officials are urged to include representatives of women, minority groups, and youth. Meetings are normally bi-annual. "Regional Foresters and Forest Supervisors not only use their advisory groups to communicate with representatives of public interests and to assess divergent views-often on highly controversial issues of public policy-but also as a device to generate support for Forest Service actions, plans, programs and innovations." $1 \mathrm{id}$. at III-225 to -226 . The same Study concluded that "[t]he Forest Service consults with special interest organizations on a relatively regular basis at the local, Forest and Regional levels. Organizations range from conservation groups to particular resource-oriented entities. The Service also consults the public througlı advisory boards, and informally. In large part, however, these efforts are informative and educational rather than consultative. Decision-making responsibility is rarely shared with outside groups." Id. at I-14. 


\section{CONCLUSION}

The contemporary environmental movement is peopled by some who call for an immediate and total re-ordering of American values and by others who believe that change can only come incrementally. This Article is largely addressed to the latter group and seeks to show how thoughtful adjustments in existing management systems can produce higher levels of environmental protection. In addition, the systematic changes suggested here require the production and publication of extensive inforination showing the environmental consequences of proposed development activities. These disclosures, hopefully, will stimulate changes in public attitudes that will generate further pressures for environmental protection in the future.

There are many roles for lawyers in the evolution and implementation of new systems for environmental protection. ${ }^{177}$ Those wlio follow the approach presented here may be inside or outside of government. Those attacking environmental problems from the outside will seek ways for opening the systems to greater public scrntiny, to thirdparty technical review, to sliaring of decision power, to the use of higher standards of scientific inquiry and professional planning and management, and to more effective and stringent enforceinent practices. These efforts will be facilitated, hopefully, by statutes like the National Environmental Policy Act ${ }^{178}$ that require sensible agency decision processes, and by statutes and judicial determinations that provide standing to environmental organizations to bring relevant law suits, ${ }^{179}$ and

177. See text accompanying notes 1-5 supra.

178. 42 U.S.C. $\$ \$ 4321-47$ (Supp. V, 1970).

179. Statutes such as Michigan's Euvironmental Protection Act of 1970 [MICH. CoMP. LAwS ANN. \$§ 691.1201-07 (Supp. 1970)] provide a comprehensive grant of standing. Section 2(1) provides that any government agency, "person," or "legal entity" may seek equitable rehef against any other governmental agency, "person," or "legal entity for the protection of the air, water and other natural resources and the public trust therein from pollution, impairment, or destruction." Other state legislatures (for example, California, Colorado, Texas) have heard proposals similar to the Michigan one, but, as yet, have not passed them. SATURDAY REviEw, Oct. 3, 1970, at 55.

Federally, S. 3575, 91st Cong., 2d Sess. \& 3(a) (1970), introduced as the Environmental Protection Act of 1970 by Senators Hart (Mich.) and McGovern (S. Dak.) and Representative Udall (Ariz.) made similar provisions for private citizen standing. As of the time this Article was ready for publication, the Bill had not been voted upon.

For cases which have broadened standing requirements enabling environmental organizations to bring law suits, see, e.g., Association of Data Processing Serv. Org. Inc. v. Camp, 397 U.S. 150 (1970); Office of Communication of United Church of Christ v. FCC, 359 F.2d 994 (D.C. Cir. 1966); Scenic Hudson Preservation Conf. v. FPC, 354 F.2d 608 (2d Cir. 1965), cert. denied, 384 U.S. 941 (1966); Parker v. United States, Civil No. C-1368 (D. Colo. Dec. 24, 1969); Powelton Civic Honle Owners Ass'n v. HUD, 284 F. Supp. 809 (E.D. Pa. 1968); Road Review League v. Boyd, 270 F. Supp. 650 (S.D.N.Y. 1967). 
provide entry for such organizations into the rule-making and adjudicatory processes of the agencies. ${ }^{180}$

Those lawyers inside of government will be able to accommodate such efforts. Moreover, they are im especially key positions to create new administrative structures in which the emerging stresses placed on the systems can lead to improved environmental conditions and not to their breakdown.

The approach described in this Article provides a inethodology for research and analysis. It should be especially useful in suggesting the kinds of criteria that should be used in environmental planning, the types and depth of information that is needed, and the processes that should be estabhished to apply such information effectively.

180. The Public Land Law Review Commission makes a number of recommendations of significance:

Recommendation 108: Congress should require public land management agencies to utilize rulemaking to the fullest extent possible in interpreting statutes and exercising delegated discretion, and should provide legislative restrictions to insure compliance with this goal.

The Commission buttresses this by also urging that the public participation requireinents of the Administrative Procedure Act, 5 U.S.C. $\$ \S 1001-11$ (1964), be applicable to such rulemaking: public notice and opportunity for the submission of comments and views.

Recommendation 109: Congress should direct the public land agencies to restructure their adjudication organization and procedures in order to assure (1) procedural due process; (2) greater third party participation; (3) objective administrative review of initial decisions; and (4) more expeditious decision-1naking.

Public Land Law Review Comm's, supra note 145, at 251-54. 


\section{California Law Review}

\begin{tabular}{lll}
\hline \hline VoL. 58 & NoVEMBER 1970 & No. 6 \\
\hline \hline
\end{tabular}

\section{BOARD OF EDITORS}

Notes \& Comments

KENT Sinclatr, JR.

D. Rebecca SNow

PetrR J. AsChenBRENNER

JAMES R. FARRAND

Paul E. Gilbert

Paul W. GlenN

Michael L. MeYers

BRUCE S. Ross

Kent A. Russell

JAMES TOLEDANO

MerRick JohN BobB

WiLliam M. Chamberlatn

Diane D. Eames

ROBERT ERICSON

Gene Harter

ElLyn A. Hershman

DAVID M. ACHTERKTRCHEN

ROBERT C. BARRETT

Steven A. Brick

LAWRENCE R. BROWN

MARY Jo ChRISTENSEN

JoHN F. DAVIS

STEVEN M. DRUKER

HENRY C. EAMES, JR.

AUBAN ANN EISENHARDT

CEARLES R. FARRAR, JR.
Editor-in-Chief

JOSEPH T. KIEFER

Chief Managing Editor

RoBert D. EVANS

\section{Articles}

WIILIAM F. COOK

STEVEN Finel

Maria TANRENSON

$$
\text { Managing }
$$

DARVISH M. KORDESTANI

Michael George Kozak

Book Reviews

J. Michael Brennan

MARY DUNLAP

\section{Associate Editors}

JUDITH G. KLEINBERG

JOHN E. MASON, JR。

ROBIN MEADOW

Dodglas alan Oglesby

LAWRENCE B. ORDOWER

Richard L. Parrish

\section{Second Year}

JAMES C. FOWLER

HAROLD FRIEDMAN

CAROL G. HAMMERTT

DAVID L. HAMMETT

JIMMIE HARRIS

ROBERT L. HARRIS

SPENCER R. KATTZ

DENNIS S. KaRJALA

Serila S. Kato

RICHARD MARCUS

THOMAS M. MURRAY

Administrative Aide

SUSAN G. VEOA
Research

G. KIP EDWARDS

DAVID R. ANDREWS

Charles H. Hurd

Dovglas M. Laurice

ROBERT LEVY

Supreme Court Editor

GREGORY J. HODBS, JR.

Executive Editor

William BiLLingsLea, Jr.

Richard L. Perez

OMar PETRONa

Peter E. SheehaN

MARGaret SHeRWOOd

Michael B. SimON

ROBERT D. STRATMORE

Carol Bruch Myers

ELAINE T. NELSON

LYNN H. PASAHOW

REX PERSCHBACHER

THOMAS B. ROSENDERG

ROBERT K. SCHIEDELHUT

MARK HAROLd SHENFIELD

SUSAN J. TAMURA

SCOTT R. WILLERT

STEPHEN ZAMORA 


\title{
Ecology Law Quarterly
}

\section{BOARD OF EDITORS}

\author{
Editor-in-Chief \\ WILLIAM M. ChaMrberLaIN \\ Managing Editor \\ ELLyn ADRIENNe HERshiman
}

Comments

JERAID W. HUNTER

Book Reviews

Articles

Carol Emory Casto

ROBERT E. LUTZ, II

Associate Editors

RICHARD J. MADDIGAN

JOHN E. MASON, JR.

STEPHEN C. MCCAFFrEY

Terence J. O'Toole

Members of the Board

Bruce Mrchaez Boyd

WILLIAM P. BRYSON

Alan Bradford Burdict

William Patrick Daley

Gayle L. Dukelow

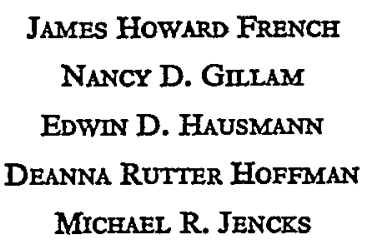

Frederick L. MCKNIGHT
ALAN F. NECKRTTZ

LAWRENCE B. ORDOWER CIYN SMITH, III

L. WIIIIAM Youmans, III ROSALYN S. ZAKHEIM

Administrative Aide

ISABEL MEDFORD 